\title{
Article \\ Effect of Time, Temperature and Stirring Rate Used in the First Step of the Synthesis of SBA-15 on Its Application as Reductor of Tars in Tobacco Smoke
}

\author{
Nerea Juárez-Serrano *(D), Javier Asensio, Inmaculada Blasco, Maribel Beltrán and Antonio Marcilla (D) \\ Chemical Engineering Department, University of Alicante, Apartado 99, 03690 Alicante, Spain; \\ javier.asensio@ua.es (J.A.); inma.blasco@ua.es (I.B.); maribel.beltran@ua.es (M.B.); antonio.marcilla@ua.es (A.M.) \\ * Correspondence: nerea.juarez@ua.es
}

check for updates

Citation: Juárez-Serrano, N.; Asensio, J.; Blasco, I.; Beltrán, M.; Marcilla, A. Effect of Time,

Temperature and Stirring Rate Used in the First Step of the Synthesis of SBA-15 on Its Application as Reductor of Tars in Tobacco Smoke. Catalysts 2021, 11, 375. https:// doi.org/10.3390/catal11030375

Academic Editor: Stanislaw Dzwigaj

Received: 15 February 2021

Accepted: 9 March 2021

Published: 12 March 2021

Publisher's Note: MDPI stays neutral with regard to jurisdictional claims in published maps and institutional affiliations.

Copyright: (c) 2021 by the authors. Licensee MDPI, Basel, Switzerland. This article is an open access article distributed under the terms and conditions of the Creative Commons Attribution (CC BY) license (https:// creativecommons.org/licenses/by/ $4.0 /)$.

\begin{abstract}
SBA-15 has been employed as a tobacco additive with the objective of reducing the toxic and carcinogenic components in tobacco smoke. The effect of the synthesis conditions (temperature, time, and stirring rate) on this application was studied in this paper. The SBA-15 was characterized (RDX, $\mathrm{N}_{2}$ adsorption isotherms, SEM and apparent density), mixed with the 3R4F reference tobacco, and smoked under standard conditions. The composition of the gas and condensed fractions also was analyzed. The morphology of the material plays an important role on this application and is highly influenced by the three variables studied. Long fibers show improved efficiency compared to short fibers. The tar reduction effect was improved when increasing the time of synthesis. Nevertheless, a maximum was observed with temperature $\left(40^{\circ} \mathrm{C}\right)$ and stirring rate $(700 \mathrm{rpm})$. The optimal synthesis conditions obtained were $24 \mathrm{~h}, 40{ }^{\circ} \mathrm{C}$ and $700 \mathrm{rpm}$, yielding reductions as high as $68 \%$ for tar, $67 \%$ for nicotine, and $31 \%$ for $\mathrm{CO}$. The scaling-up process has only been reported in terms of grams but never in a preindustrial scale (around $4 \mathrm{~kg}$ ), and thus the results of this analysis show a promising material with properties and behavior similar with respect to the sample synthesized at laboratory scale.
\end{abstract}

Keywords: SBA-15 synthesis conditions; reduction of tobacco toxicants; tar; nicotine; CO

\section{Introduction}

The use of tobacco plant began in America about 5000-7000 years ago and arrived to Europe in the 16th century. Since then, smoking has spread as a common social habit without much importance given to its clear addictive character for years [1]. During the last decades, the negative effects of tobacco on health, such as lung, laryngeal, oral cavity and pharyngeal cancers [2], cardiovascular diseases [3], respiratory problems [4], reproductive effects, the incorrect evolution of the fetal development, risk factor for neurodevelopmental and behavioral problems in children [5] between others, have been confirmed. For this reason, during more than 20 years but especially during the past recent years, governmental organizations have paid much attention to the indicators that predict the maintenance of tobacco consumption. Moreover, to fight against the massive consumption of tobacco, they have tried to eliminate this practice through regulations or by increasing taxes on tobacco [6-10].

To control the evolution of these measures, some inquiries have focused on the tracing of reduction of tobacco consumption $[9,11]$; although the number of smokers is decreasing in recent years, the percentage of smokers is still worrisome [9,12]. From this perspective, it can be confirmed that tobacco use is a practice that is still ingrained in current societies, and it would be necessary to work out more measures for reducing the effects of tobacco on health.

One of the new measures adopted in 2016 by the European governments was the prohibition of the addition of some additives to tobacco flavors, such as vanilla, alcohol, candy, and menthol. The last one, with an additional period of time until 2020. These 
substances encourage the consumption of tobacco since its good taste makes tobacco much more appealing and it increases the addiction [13], especially of young people.

However, there is a series of additives that produce a different effect to those previously described. During the last years, the use of catalysts as an additive in tobacco or in some of the elements that conform the cigarettes is being studied [14-16]. The presence of the catalysts in the combustion process of tobacco produces a significant effect in the reduction of the toxic compounds generated during the smoking process. In this sense, Marcilla et al. [17] studied the effect of four catalysts in the composition of mainstream tobacco smoke in a commercial tobacco brand. They could observe that these materials reduced the yields of most toxic and carcinogenic compounds on tobacco smoke, especially in the case of Al-MCM-41.

Moreover, the structure and morphology of these substances are key factors in toxic substances reduction in smoking tests. Lin et al. [18] analyzed the effect of applying different catalysts such as Na-MFI, NaY, MCM-41 or SBA- 15 on the reduction of tobacco nitrosamines (TSNAs) in mainstream smoke. These authors determined that the zeolites added in Burley cigarettes could reduce between $18 \%$ and $35 \%$ of the TSNAs present in the smoke and that their morphology and aggregation of crystal or primary particles modify the levels of reduction.

The SBA-15 is a mesoporous material with promising properties, and it has been employed for multiples applications such as adsorption [19], storage [20], support, and catalysis $[21,22]$. In addition, novel applications for this material have been developed in recent years, for example, as a support in oxidative desulfurization processes [23], support in the synthesis process of stilbene and chalcone derivatives with biological activity against influenza A virus by self-, cross-, and rig-closing metathesis procedures [24], or support of palladium catalysts in methane combustion and NOx reductions [25].

The properties of SBA-15 mesoporous materials have been studied for years by different authors, who reported the effect on the variables of synthesis on the corresponding structure and morphology developed [26-29]. For instance, Lee et al. [30] studied the effect of temperature and stirring rate on the morphology of the material. They were able to observe that at $500 \mathrm{rpm}$, the structure was modified by increasing the temperature from spheres to hexagonal columns, rice grains, rods and nanodonuts. However, at $300 \mathrm{rpm}$, rods were generally obtained. On the other hand, Fulvio et al. [31] analyzed the influence of time and temperature at the hydrothermal treatment step of the synthesis using two silica sources; sodium metasilicate and tetraethylorthosilicate. In their study, they concluded that the increase of reaction time produced a reduction in micropore volume and surface area and an increase in the width of the mesopores. They also observed that at a high temperature $\left(120^{\circ} \mathrm{C}\right)$, the mesopore volume and width exhibited values slightly higher than for the samples prepared at $100^{\circ} \mathrm{C}$.

Nevertheless, there are very few works studying the effect of the SBA-15 synthesis variables on the reduction of tobacco smoke toxicants. In a previous paper [32], we reported the effect of time, temperature, and the amount of supernatant liquor in the hydrothermal SBA-15 treatment on the properties of the material synthesized as well as the effect on the tobacco toxicity reduction. In order to provide more insight on the effect of the SBA-15 synthesis variables on its effect as a tobacco toxicant reducer, the objective of the present paper is analyzing the influence of the time and the stirring rate during the initial SBA-15 precipitation stage prior to the hydrothermal treatment. We focus on the SBA-15 properties and their effect on the mainstream smoke components when added to tobacco. To reach this goal, 3R4F tobacco reference was selected and mixed with the samples synthesized and smoked under the ISO smoking regime. 


\section{Results and Discussion}

\subsection{Synthesis of $S B A-15$}

Table 1 shows the textural parameters obtained from the adsorption isotherms, the apparent density, and the length of the hexagonal unit cell by DRX, of the different materials synthesized.

Table 1. Structural properties of the samples synthesized at different time, temperature, and stirring rate in the first step of the synthesis.

\begin{tabular}{|c|c|c|c|c|c|c|}
\hline Sample & $\operatorname{SBET}^{a}\left(\mathrm{~m}^{2} \cdot \mathrm{g}^{-1}\right)$ & $\mathrm{Vt}^{\mathrm{b}}\left(\mathrm{cm}^{3} \cdot \mathrm{g}^{-1}\right)$ & $\mathrm{Vm}^{\mathrm{c}}\left(\mathrm{cm}^{3} \cdot \mathrm{g}^{-1}\right)$ & $\mathrm{DP}^{\mathrm{d}}(\mathrm{nm})$ & $\rho_{\mathrm{a}}^{\mathrm{e}}\left(\mathrm{g} \cdot \mathrm{cm}^{-3}\right)$ & $a_{0}{ }^{f}(\mathrm{~nm})$ \\
\hline $\mathrm{t} 6$ & 955 & 1.034 & 0.364 & 6.2 & 0.048 & 11.7 \\
\hline $\mathrm{t} 15$ & 932 & 1.037 & 0.366 & 6.1 & 0.061 & 11.4 \\
\hline $\mathrm{t} 20$ & 843 & 0.913 & 0.329 & 6.1 & 0.045 & 11.4 \\
\hline $\mathrm{t} 24$ & 861 & 0.943 & 0.357 & 5.9 & 0.049 & 11.6 \\
\hline T25 & 890 & 0.917 & 0.350 & 5.6 & 0.109 & 11.3 \\
\hline T30 & 901 & 0.912 & 0.368 & 5.6 & 0.095 & 11.4 \\
\hline $\mathrm{T} 40$ & 861 & 0.943 & 0.357 & 5.9 & 0.049 & 11.6 \\
\hline T55 & 828 & 0.859 & 0.336 & 6.5 & 0.061 & 12.3 \\
\hline R400 & 973 & 1.041 & 0.381 & 6.1 & 0.046 & 11.7 \\
\hline R700 & 861 & 0.943 & 0.357 & 5.9 & 0.049 & 11.6 \\
\hline R1000 & 933 & 1.007 & 0.378 & 6.2 & 0.062 & 11.7 \\
\hline
\end{tabular}

(Sample synthesized at $24 \mathrm{~h}, 40^{\circ} \mathrm{C}$, and $700 \mathrm{rpm}$ is common to the three series done. To compare results, this sample has been named as $\mathrm{t} 24, \mathrm{~T} 40$, and R700 depending on the study discussed). ${ }^{\mathrm{a}}$ BET surface area [33]. ${ }^{\mathrm{b}}$ Total pore volume at $\mathrm{P} / \mathrm{P}_{0}=0.995 .{ }^{\mathrm{c}}$ Dubinin micropore volume [34]. ${ }^{\mathrm{d}}$ Pore diameter BJH method applied to the desorption branch [35]. ${ }^{\mathrm{e}}$ Apparent density. ${ }^{\mathrm{f}}$ Length of the hexagonal unit cell.

The DRX patterns of the catalysts are presented in Figures 1-3, and they present the typical diffraction planes (100), (110), and (200), which are characteristic of the hexagonal structure of SBA-15 materials [36,37]. The dimensions of the hexagonal unit cell do not present a significant variation with the variables studied (found between 11.3 and $11.7 \mathrm{~nm}$ in all cases, as shown in Table 1). The intensity of the diffraction peaks shows an increasing trend with precipitation time. Nevertheless, the temperature and agitation speed present a distinct behavior. The sample synthesized at $40{ }^{\circ} \mathrm{C}(\mathrm{T} 40)$ reaches the greatest intensity for the peak (100) with respect to the rest of the samples. Additionally, the ratio $(110) /(200)$ is higher for the pair of samples obtained at higher temperature compared to those synthetized at lower temperatures, which shows the restructuring of the net during condensation [36]. The stirring rate also has a marked effect, and the sample at $700 \mathrm{rpm}$ shows the maximum intensity.

The $\mathrm{N}_{2}$ adsorption/desorption isotherms of all samples (Figures 4-6) have a typical behavior of a Type IV isotherm. It can be seen that all of them are very similar.

Table 1 shows the results of an area BET surface, total pore volume, micropore volume, and pore diameter, obtained from the adsorption isotherms of $\mathrm{N}_{2}$ at $77 \mathrm{~K}$. With respect to the effect of the precipitation time, the micropore volume shows slight variations, remaining practically constant. The BET area and the total pore volume show a somewhat dispersed behavior, although they seem to decrease with the reaction time. The pore diameter presents a clearer trend, in which again, a decrease is observed with the reaction time. This behavior may be due to the formation of mid-sized mesopores that connect the main channels [38,39], accompanied by the reduction in micropore volume. A similar behavior was observed by other authors when studying this variable. For example, Benamor et al. [36], among other aspects, studied the effect of the duration of the precipitation process. They analyzed this effect in a series prepared without applying the hydrothermal treatment. They observed similar trends and, in this way, considered irrelevant the influence of this variable on the properties of the materials. These authors argued that, over $2 \mathrm{~h}$, the properties of the materials were not significantly modified. However, they did highlight a significant influence in relation to the morphology of the materials and the appearance of fibers in the structure. The materials obtained by these authors show much lower adsorption capacities 
than the samples obtained in the present work. This reduced adsorption capacity was related to the lack of hydrothermal treatment in their case. In our case, the treatment was applied at $80^{\circ} \mathrm{C}$, which justifies the greater development of the porous texture, according to other studies $[20,40,41]$.

As with time, the temperature also shows a dispersed behavior in the case of the BET area and the total pore volume. Roughly, the BET area seems to be reduced when temperature increases, while the total pore volume does not show a clear trend. In this case, the pore diameter also manifests a clearer trend, where its value increases when the study variable increases. The micropore volume has similar values for all samples. These type of results have been already observed by other authors in previous works [42].

When studying the effect of stirring rate, it can be seen that the parameters that determine the porous texture have a minimum value for the sample obtained at $700 \mathrm{rpm}$. Carrero et al. [43] in their results at low stirring rates found that this variable did not show a clear trend in the texture parameters studied.

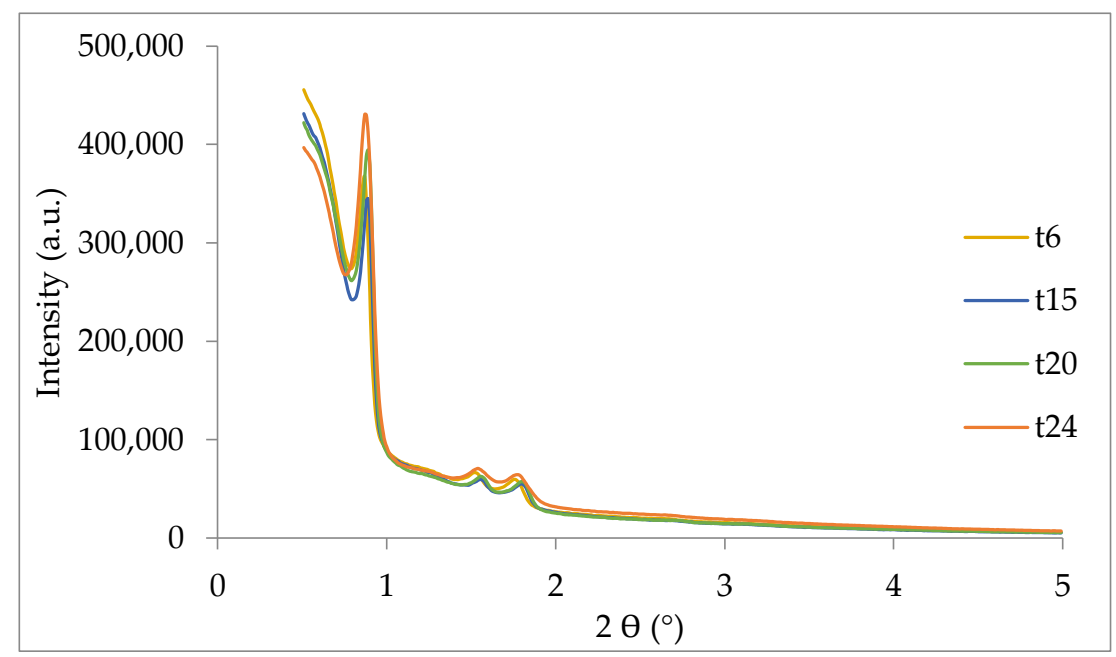

Figure 1. Low angle X-ray diffraction patterns of samples for the study of the influence of time.

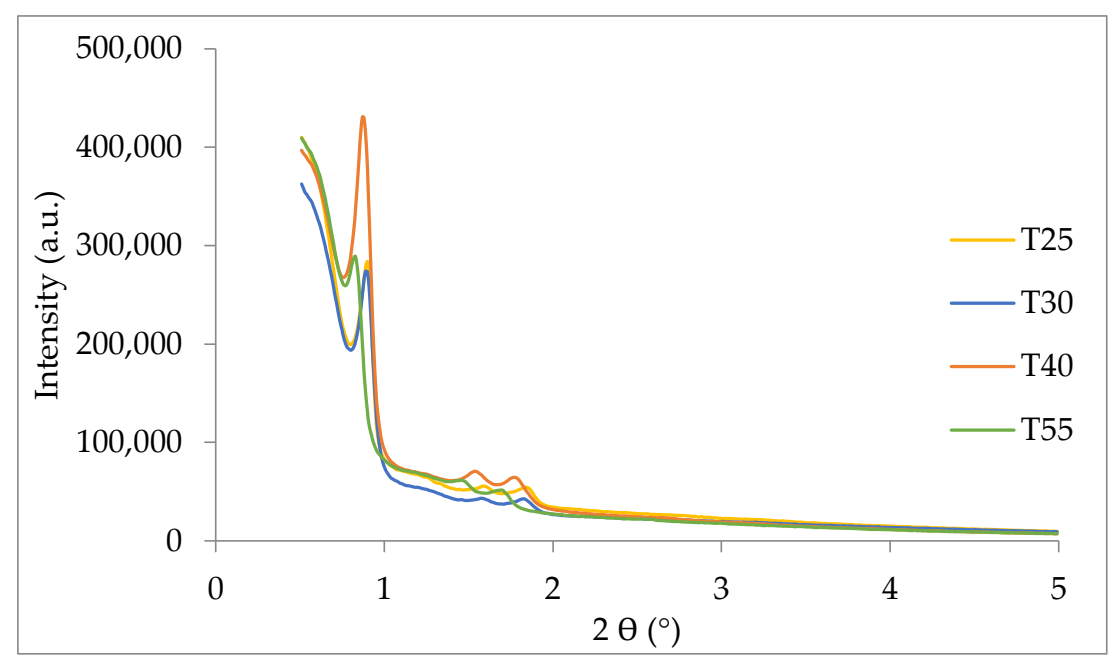

Figure 2. Low angle X-ray diffraction patterns of samples for the study of the influence of temperature. 


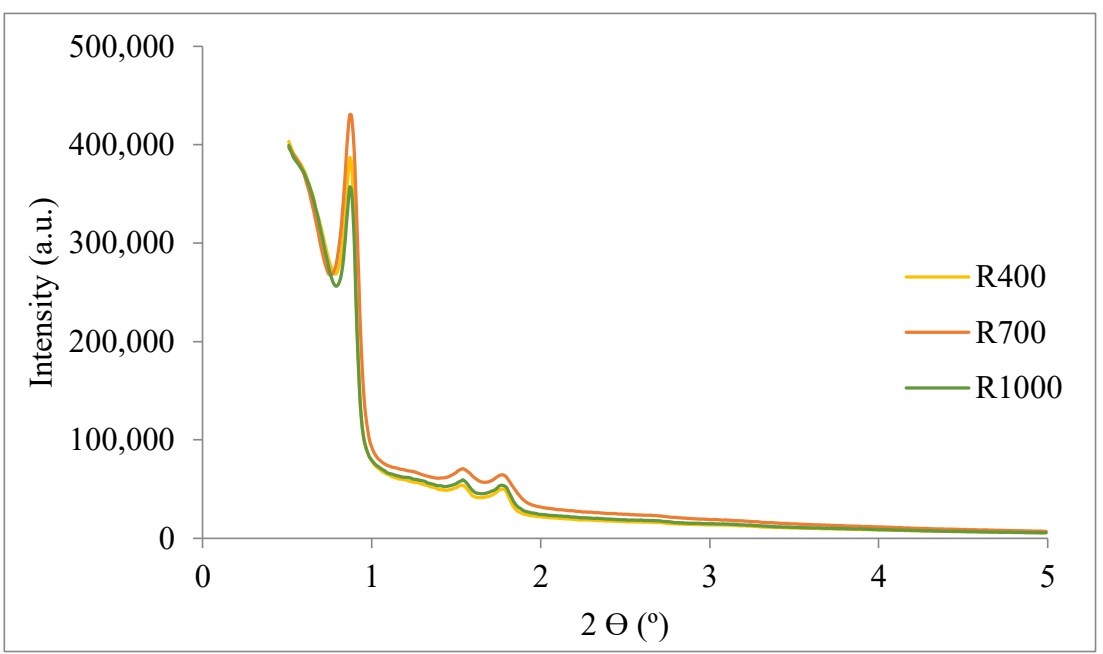

Figure 3. Low angle X-ray diffraction patterns of samples for the study of the influence of stirring rate.

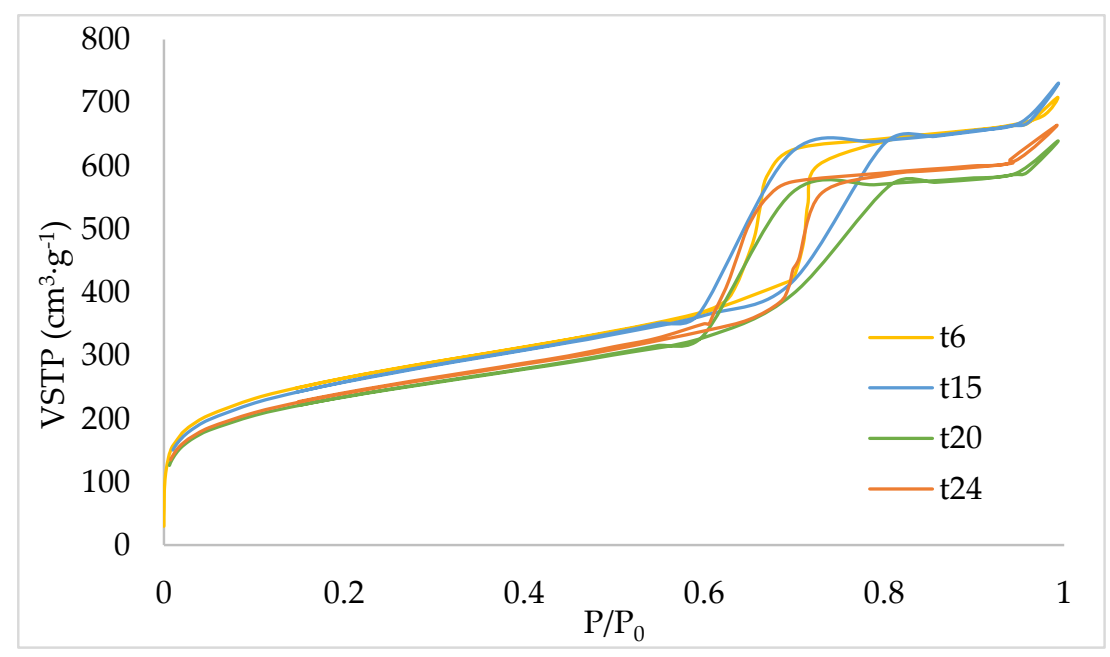

Figure 4. $\mathrm{N}_{2}$ adsorption isotherms corresponding to the samples for time study.

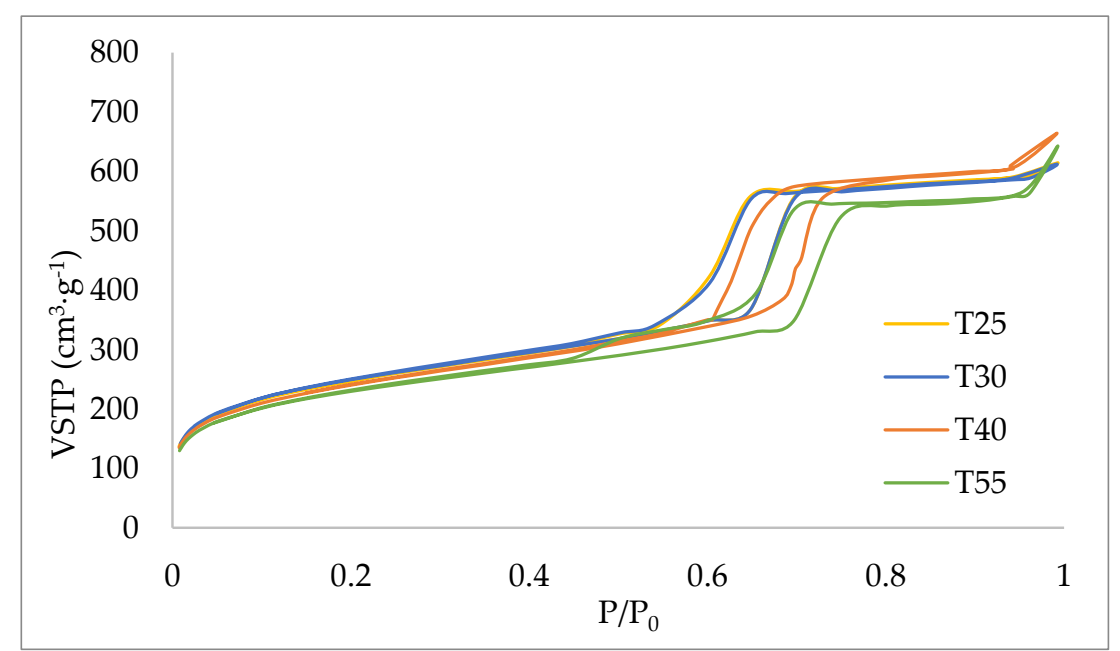

Figure 5. $\mathrm{N}_{2}$ adsorption isotherms corresponding to the samples for temperature study. 


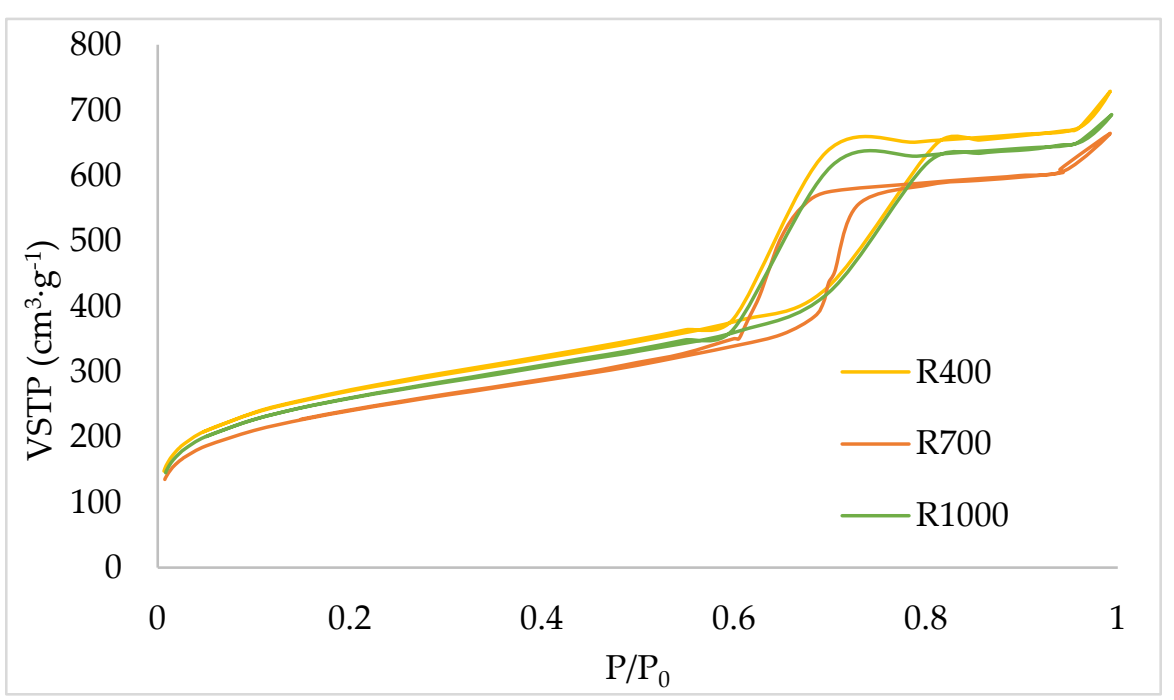

Figure 6. $\mathrm{N}_{2}$ adsorption isotherms corresponding to the samples for stirring rate study.

The values of the apparent density of the samples are presented in Table 1. As we have already indicated, this property is not frequently determined in this type of studies; in fact, we have only found a reference where this parameter is studied, and in addition, there was no special emphasis on its relevance [44]. However, it has proven to be of great importance in the application studied, as we showed in a previous work [45]. The microscopy helps in understanding the structure developed by the materials as well as the value of the apparent density, and thus we discuss both results simultaneously.

Apparent density presents a maximum value at $15 \mathrm{~min}$, while the rest of the reaction times yield similar values of this property. This behavior may be related with the morphology of the materials (see Figure 7a-d). The samples synthesized at 6, 20, and $24 \mathrm{~h}$ present well-defined and relatively long fibers; by contrast, the sample at $15 \mathrm{~h}$ presents shorter and somewhat thinner fibers. In the case of temperature, the sample at $40^{\circ} \mathrm{C}$ presents the minimum value. Again, the micrographs may provide an explanation to this behavior. The samples at $25^{\circ} \mathrm{C}$ and $30^{\circ} \mathrm{C}$ (Figure 7e,f) do not present fibers at all but conglomerates of cylindrical particles (the so-called rods in literature) of small size. At $40^{\circ} \mathrm{C}$ (Figure $7 \mathrm{~g}$ ), the material presents the typical fibrous morphology, which are responsible for the low apparent density as a consequence of the lean packing of this type of material, as compared with those with less elongated particles. At $50{ }^{\circ} \mathrm{C}$ (Figure 7h), fibers are also present, although the apparent density shows a certain increase. The stirring rate shows an increasing trend in the apparent density as a consequence of the break of the fibers as the stirring rate increases (see Figure $7 \mathrm{~g}-\mathrm{i}$ ).

As would be expected in view of the results, the density of the compounds that presented agglomerated structures (particles poorly elongated) shows a greater capacity for compaction, resulting in a higher density values, i.e., those close to $0.1 \mathrm{~g} \cdot \mathrm{cm}^{-3}$. On the contrary, fibrous materials have low compaction capacity and thus present lower apparent densities. 

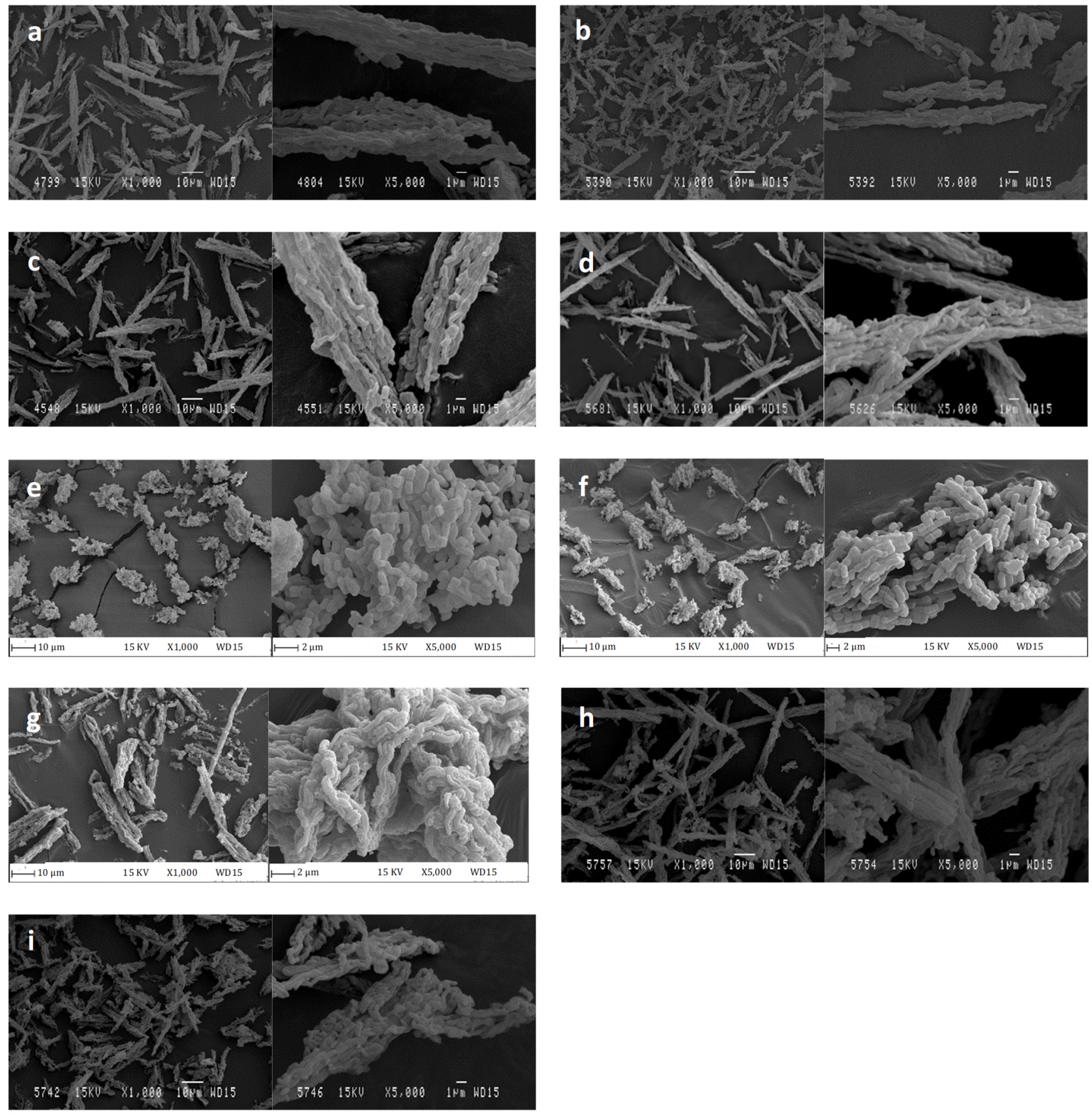

Figure 7. SEM micrographs of the synthesized SBA-15 catalyst: (a) t6, (b) t15, (c) t20, (d) t24 (also named samples T40 and R700), (e) T25, (f) T30, (g) T55, (h) R400, and (i) R1000 at two different magnifications.

\subsection{Smoking Experiment Results}

The smoking experiments were developed following the methodology used in previous works, and the analysis of the results obtained were analyzed and presented in a similar way [32,45]. The reductions were calculated as the amount of a given compound or family of compounds obtained in the smoke when smoking the reference tobacco (without the catalyst), minus the amount obtained when smoking in the presence of the catalyst, divided by the amount obtained without the catalyst, expressed as a percentage. Results correspond to total particulate matter (TPM) composition (43 compounds identified from the extract of the Cambridge filter), nicotine, carbon dioxide, carbon monoxide, total gas, and gas phase composition (31 compounds). These compounds represent around $90 \%$ of 
the area of the chromatograms of the gas fraction and about $95 \%$ of those of the condensed fraction. The reduction percentages for each one of the compounds detected among these $31+43$ followed in the different tests; these are included in Appendices A and B.

Table 2 shows the reduction percentages obtained with the SBA-15 synthesized at different times, temperatures, and stirring rates in the precipitation process for TPM, nicotine, carbon dioxide, and carbon monoxide.

Table 2. Smoking experiments results. Reduction of total particulate matter (TPM), nicotine, $\mathrm{CO}_{2}$, $\mathrm{CO}$ and gases expressed in percentage.

\begin{tabular}{cccccc}
\hline Sample & TPM (\%) & Nicotine $(\%)$ & $\mathbf{C O}_{\mathbf{2}} \mathbf{( \% )}$ & $\mathbf{C O}(\mathbf{\%})$ & Total Gas $\mathbf{( \% )}$ \\
\hline t6 & 60.3 & 56.0 & 29.8 & 34.5 & 37.5 \\
t15 & 55.1 & 49.5 & 22.4 & 18.8 & 32.1 \\
t20 & 59.7 & 55.0 & 20.5 & 24.3 & 25.2 \\
t24 & 68.1 & 66.8 & 23.4 & 31.0 & 27.8 \\
\hline T25 & 43.8 & 50.4 & 13.2 & 16.7 & -3.1 \\
T30 & 45.9 & 50.5 & 13.1 & 17.5 & -4.0 \\
T40 & 68.1 & 66.8 & 23.4 & 31.0 & 27.8 \\
T55 & 41.3 & 48.4 & 16.2 & 21.2 & -6.6 \\
\hline R400 & 51.7 & 51.4 & 17.5 & 13.3 & 19.3 \\
R700 & 68.1 & 66.8 & 23.4 & 31.0 & 27.8 \\
R1000 & 42.5 & 34.1 & 21.4 & 19.9 & 25.0 \\
\hline
\end{tabular}

Sample synthesized at $24 \mathrm{~h}, 40^{\circ} \mathrm{C}$ and $700 \mathrm{rpm}$ is common to the three series done. To compare results this sample has been named as $\mathrm{t} 24, \mathrm{~T} 40$ and R700 depending on the study discussed.

In general terms, all samples show acceptable reduction values of all the compounds or groups of compounds presented in Table 2, reaching the maximum at $24 \mathrm{~h}$ of precipitation, $40{ }^{\circ} \mathrm{C}$ of temperature, and $700 \mathrm{rpm}$. However, in volatile compounds referred as gases, the sample that was synthesized at $6 \mathrm{~h}$ reaches values even higher than those obtained at $24 \mathrm{~h}$.

Analyzing the effect of synthesis time, it can be observed that, except the sample synthesized at $6 \mathrm{~h}$, the reductions in TPM and nicotine increased with time. Nevertheless, the gases show the opposite trend. Among the textural variables, the apparent density is the one that presents the better correlation with the reduction values obtained. A lower effect can be observed when increasing the density, which may be related to a worse dispersion of the catalyst particles in the tobacco when preparing the smoking mixture, as well as to a worse catalytic effect on the secondary reactions of the tars deposited on the catalyst when the front of the reaction progresses through the cigarette cylinder between puffs.

The effect of temperature is very significant, and a maximum in TPM and nicotine reduction, carbon oxides, and total gases was observed for the sample synthesized at $40{ }^{\circ} \mathrm{C}$. Again, the correlation with the apparent density is evident, and the sample with the lowest density is the one providing the best results. The total pore volume also presents a positive correlation with the reduction results.

In the series of stirring rate, the effect of the apparent density and the structure of the fiber are clearly revealed, these properties cause a marked worsening of the catalytic capacity in the sample obtained at $1000 \mathrm{rpm}$, which is the sample presenting the largest value of the apparent density.

Considering the great variety of components present in the smoke, we grouped them into the following families of compounds: paraffins, olefins, aromatics and aldehydes for those collected in the volatile fraction; and nitrogenous, carbonyls, epoxies, phenols and aliphatics for those collected in the condensed fraction. In both, the other compounds analyzed and that have not been grouped into any of these families were regrouped as "others". In general, it can be observed that the different families analyzed follow similar trends, and so they will not be commented on separately with the objective of not to be repetitive.

Figure 8 represents the reduction percentages of the different families analyzed in the condensed fraction when studying the influence of time of synthesis. Figure 9 shows 
the results corresponding to the gas fraction. It can be observed that, in general, with the exception of the sample synthesized after $6 \mathrm{~h}$ of reaction, the reduction percentages increase, with the synthesis time and all the reductions being very high. The sample synthesized after $24 \mathrm{~h}$ of reaction is the one that presents the greatest reductions for all the substances. With respect to the compounds collected in the gas fraction the behavior is the opposite (as commented on when discussing the behavior of TPM and total gases) and a trend towards reducing the capacity of the SBA- 15 is observed when the reaction time increases. This fact could be related to the decrease in the volume of micropores and the diameter of the mesopores, previously commented on.

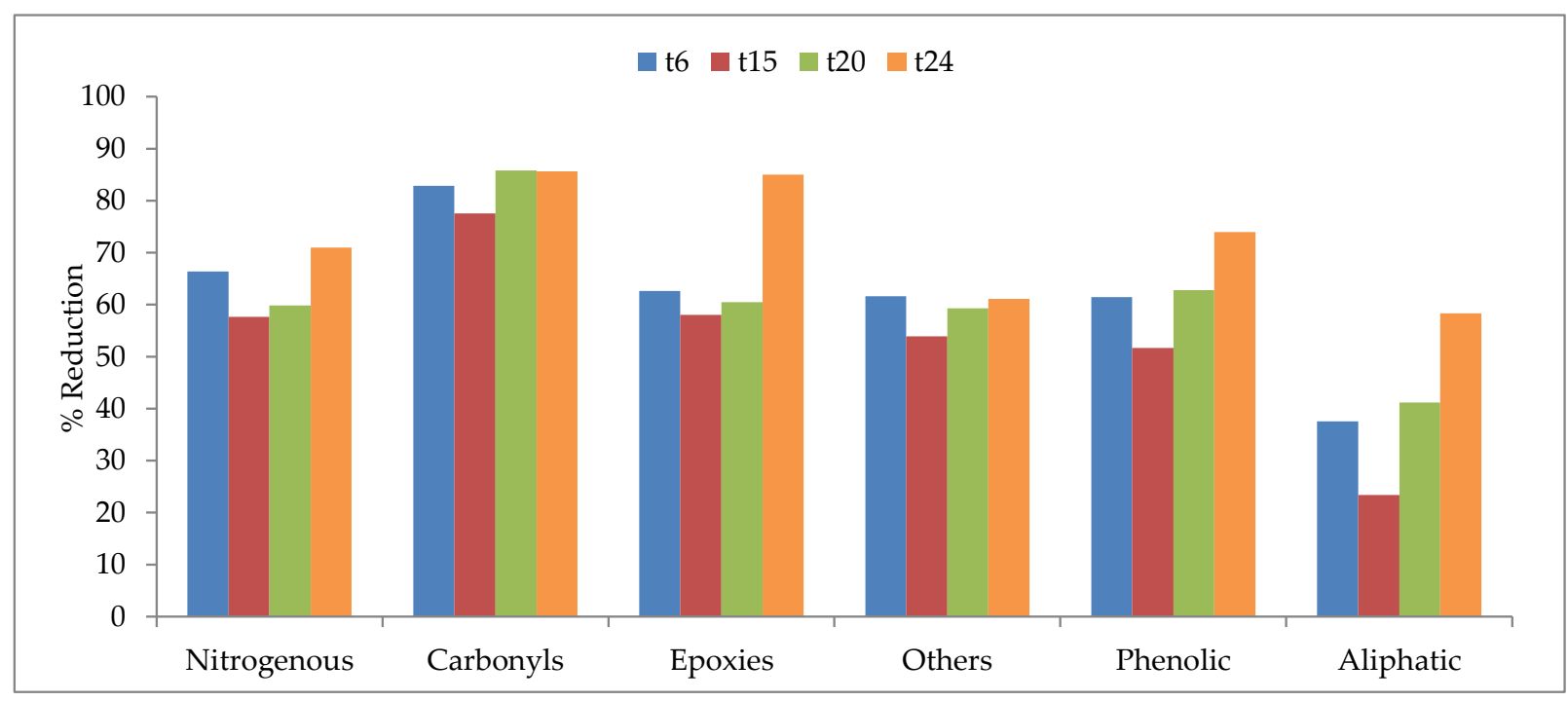

Figure 8. Reduction obtained for the different families of compounds in the total particular matter collected in the study of the time (h) at the first step of the synthesis with fixed conditions of temperature, $40{ }^{\circ} \mathrm{C}$, and stirring rate, $700 \mathrm{rpm}$.

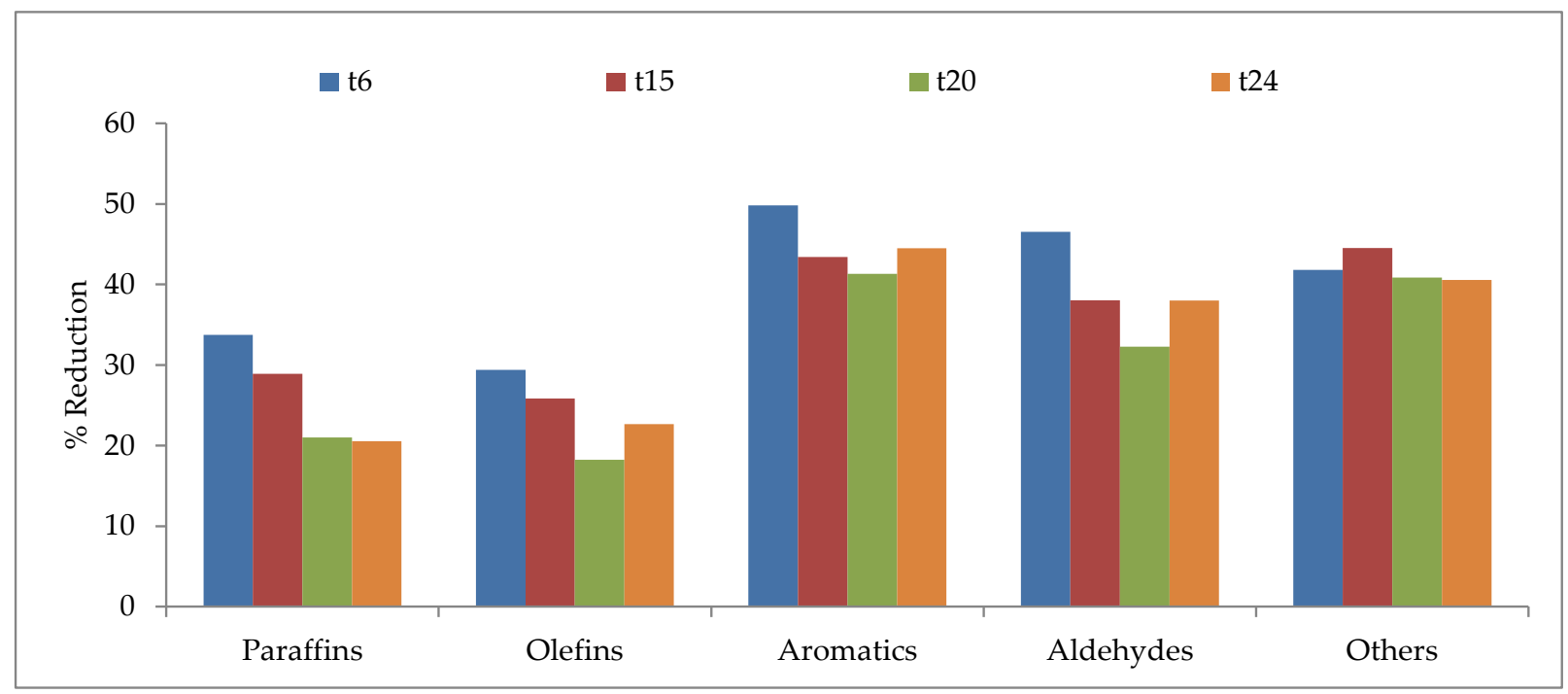

Figure 9. Reduction obtained for the different families of compounds in the gases collected in the study of the time (h) at the first step of the synthesis with fixed conditions of temperature, $40{ }^{\circ} \mathrm{C}$, and stirring rate, $700 \mathrm{rpm}$.

The effect of temperature on the precipitation process of the synthesis can be seen in Figures 10 and 11. The reductions markedly increased with temperature, especially at $40{ }^{\circ} \mathrm{C}$, and then markedly decrease. The sample synthesized at $40^{\circ} \mathrm{C}$ presents the highest reductions for all families in liquids and especially in gases. Again the apparent density, 
with a negative correlation, and the total pore volume, with a positive correlation, are the parameters presenting the best correlation with reductions observed.

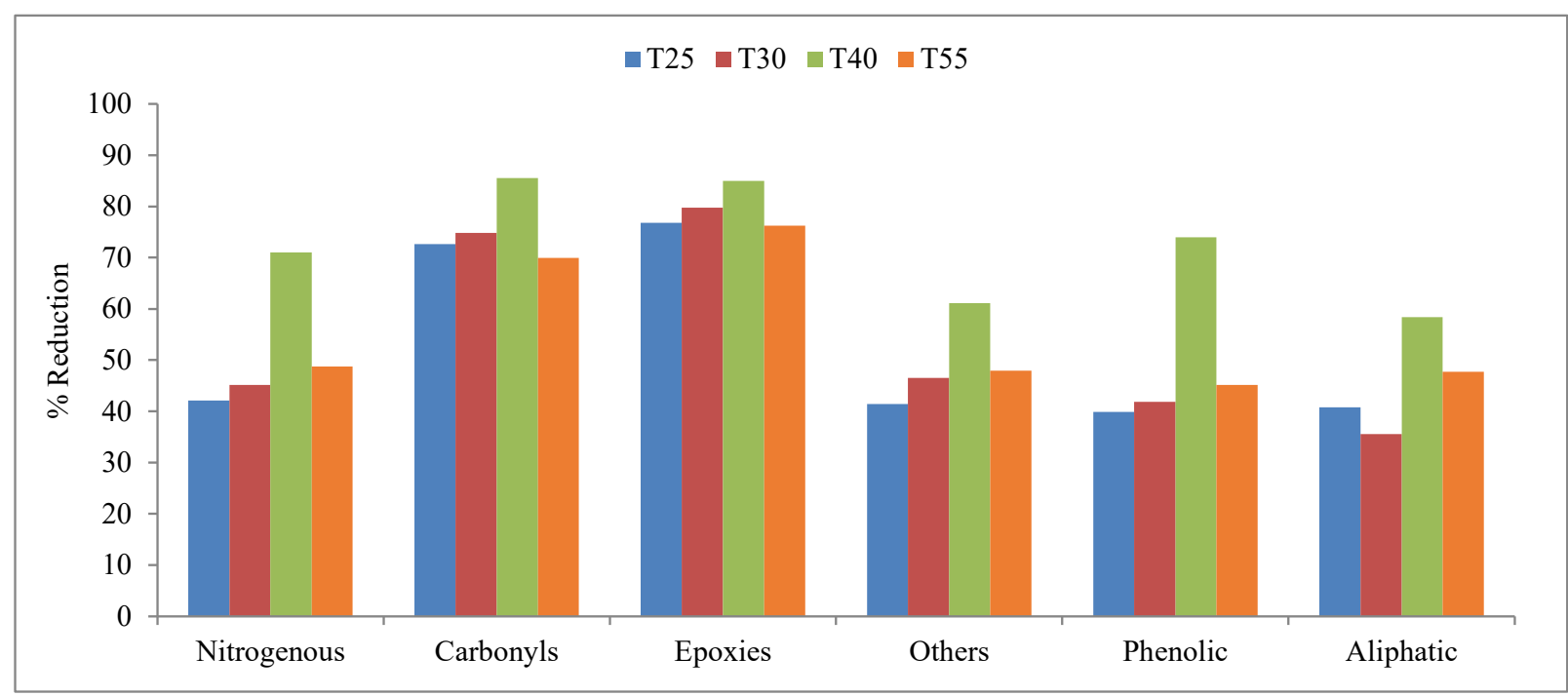

Figure 10. Reduction obtained for the different families of compounds in the total particular matter collected in the study of the temperature $\left({ }^{\circ} \mathrm{C}\right)$ at the first step of the synthesis with fixed conditions of time, $24 \mathrm{~h}$, and stirring rate, $700 \mathrm{rpm}$.

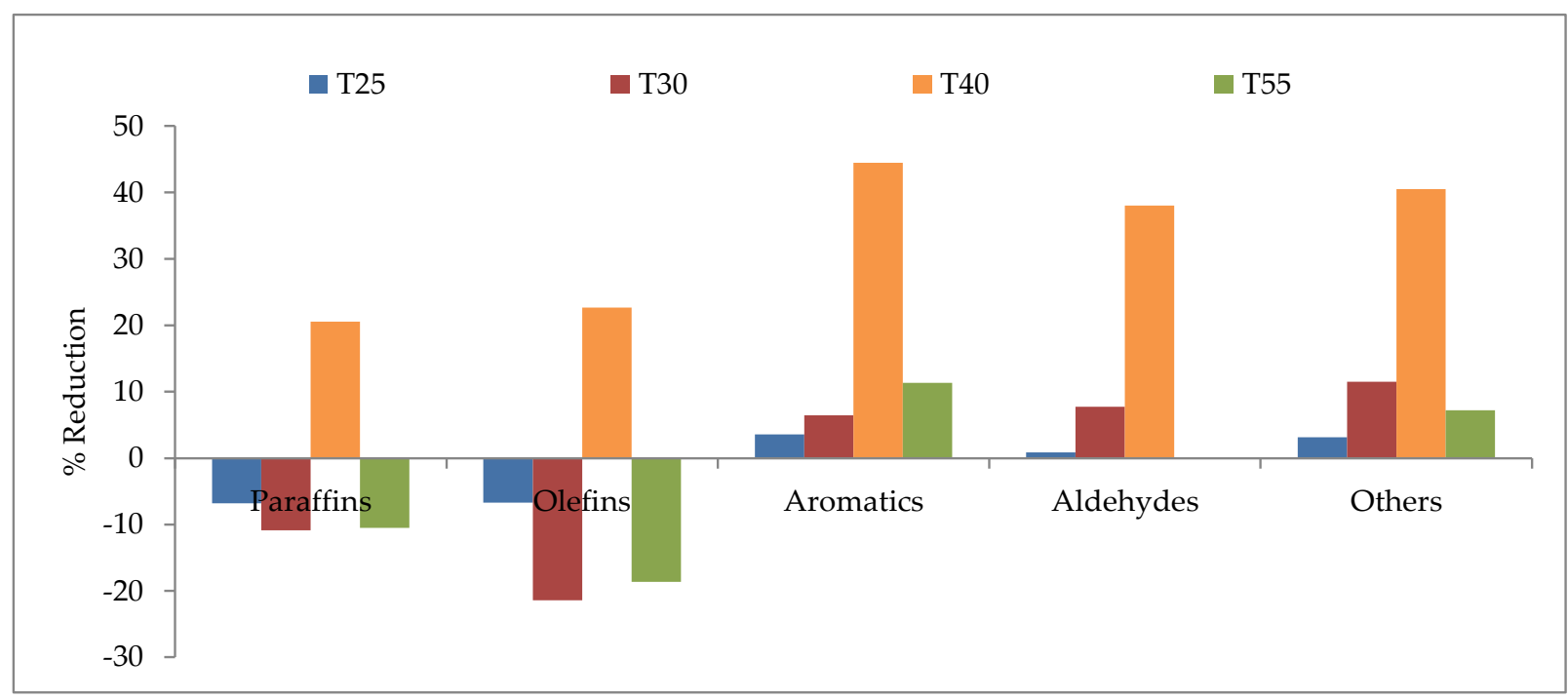

Figure 11. Reduction obtained for the different families of compounds in the gases collected in the study of the temperature $\left({ }^{\circ} \mathrm{C}\right)$ at the first step of the synthesis with fixed conditions of time, $24 \mathrm{~h}$, and stirring rate, $700 \mathrm{rpm}$.

Regarding the stirring rate effect, a maximum can be observed in practically all families of compounds, both in TPM and gases, for the samples synthesized at $700 \mathrm{rpm}$ (see Figures 12 and 13, respectively). Again, a negative effect of a too high stirring rate in the application of the SBA-15 on tobacco is evidenced. This is mainly due to the increase in apparent density and pore size, as well as the fiber fracture. 


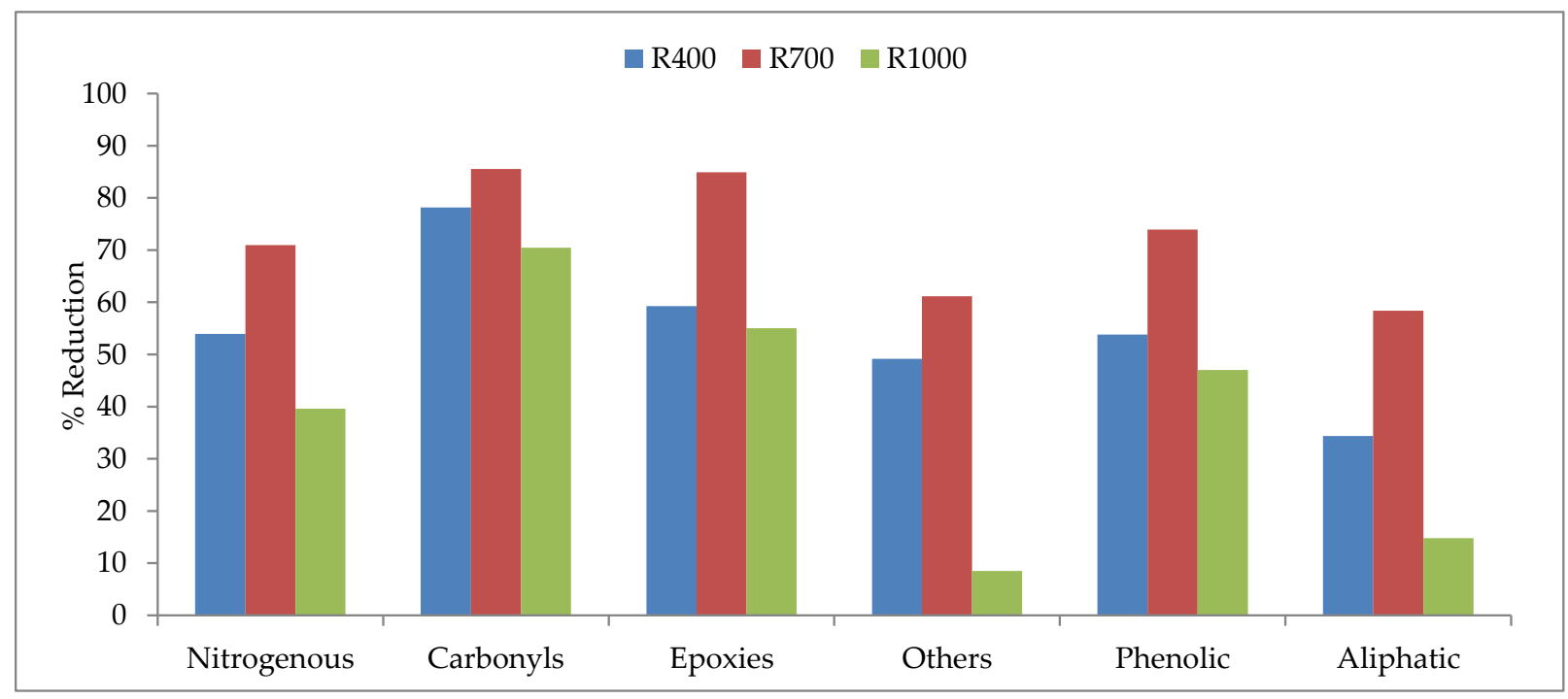

Figure 12. Reduction obtained for the different families of compounds in the total particular matter collected in the study of the stirring rate (rpm) at the first step of the synthesis with fixed conditions of time, $24 \mathrm{~h}$, and temperature $\left(40^{\circ}\right)$.

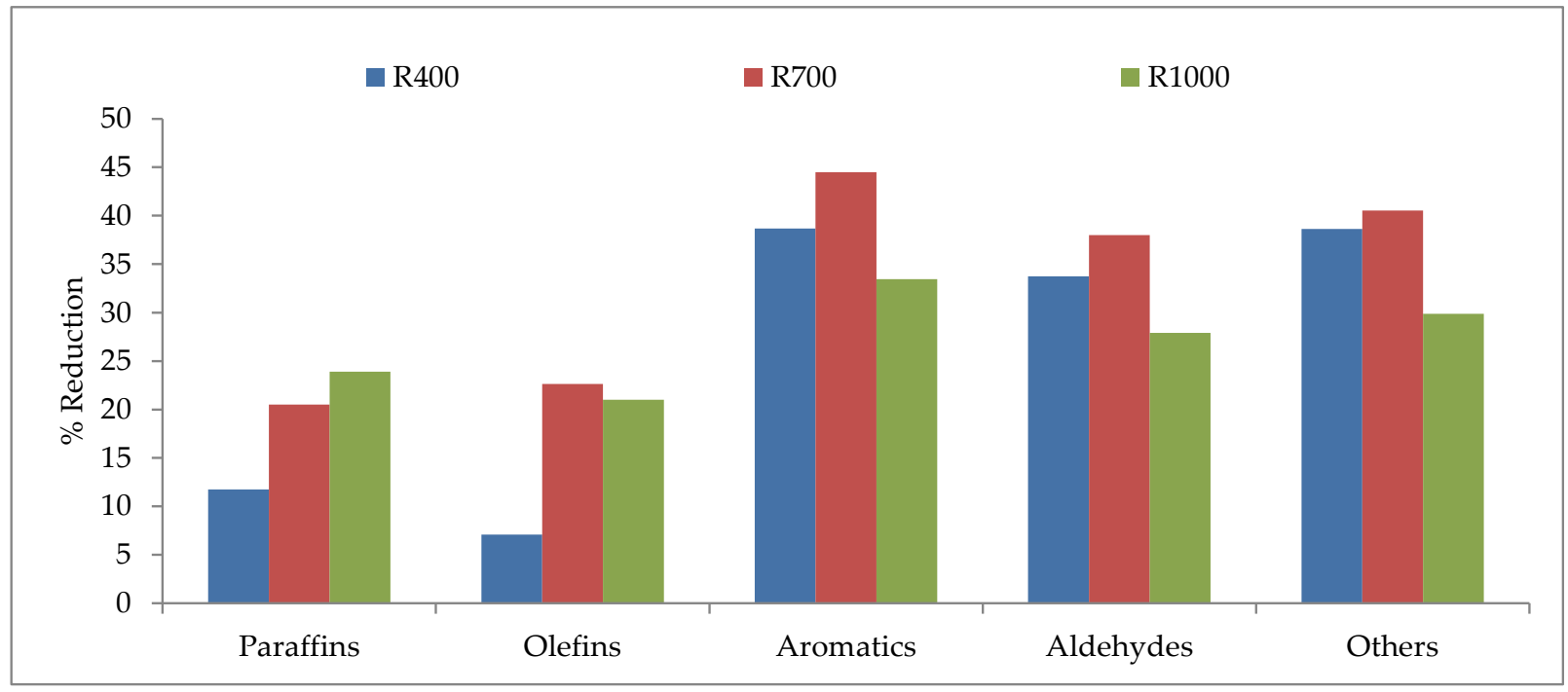

Figure 13. Reduction obtained for the different families of compounds in the gases collected in the study of the stirring rate $(\mathrm{rpm})$ at the first step of the synthesis with fixed conditions of time, $24 \mathrm{~h}$, and temperature $\left(40^{\circ}\right)$.

\section{Materials and Methods}

\subsection{Synthesis of SBA-15}

The SBA-15 materials were prepared with TEOS (tetraethyl orthosilicate) as a silica source using the method described by Zhao et al. [45] and modified by Juárez-Serrano et al. [32]. In the first step of the synthesis (precipitation), a solution of $65.63 \mathrm{~mL}$ of $\mathrm{HCl} 1.6 \mathrm{M}$ (using $\mathrm{HCl} 11.32 \mathrm{M}$, from Merck) was prepared to dissolve $1.75 \mathrm{~g}$ of Pluronic P123 surfactant (triblock poly(ethylene oxide)-b-poly(propylene oxide)-b-poly(ethylene oxide) copolymer, from Sigma-Aldrich, Schnelldorf, Germany). After $1 \mathrm{~h}, 3.67 \mathrm{~g}$ of TEOS, tetraethyl orthosilicate (from Sigma-Aldrich) was added to the mixture and maintained under the selected time, temperature, and stirring rate conditions. The hydrothermal treatment was run according to the modification described in [32], i.e., the precipitate was filtered, resuspended in 1/3 of the mother liquor in order to reduce the volume of the container, then transferred to closed bottles and kept at $80{ }^{\circ} \mathrm{C}$ during $24 \mathrm{~h}$ under static conditions. In that reference, it was shown that this treatment was as efficient as the one 
described by Zhao et al. in their original paper [45], both to develop the SBA-15 structure and properties and to reduce the toxicants in the smoking application. Finally, solids were collected by filtration, washed, and dried for $2 \mathrm{~h}$ at $100{ }^{\circ} \mathrm{C}$, calcined for $5 \mathrm{~h}$ at $550{ }^{\circ} \mathrm{C}$, and sieved.

It is well known that the time, temperature, and stirring rate in the first step of the synthesis strongly affect the properties and texture of the materials [30,36,46,47]. Nevertheless, the effect of such properties on smoking experiments has not yet been investigated. Thus, the following experimental design was developed: A temperature of $40^{\circ} \mathrm{C}$ and a stirring rate of $700 \mathrm{rpm}$ were fixed, and times of $6,15,20$, and $24 \mathrm{~h}$ were selected for studying the influence of time. The influence of temperature was studied at $25,30,40$, and $55^{\circ} \mathrm{C}$ during $24 \mathrm{~h}$ at $700 \mathrm{rpm}$. Finally, a time of $24 \mathrm{~h}$ and a temperature of $40{ }^{\circ} \mathrm{C}$ were selected for studying the influence of the stirring rate at 400, 700, and $1000 \mathrm{rpm}$. Samples were named according to the letter that represents the study, i.e., " $\mathrm{t}$ " for time in hours, " $\mathrm{T}$ " for temperature in ${ }^{\circ} \mathrm{C}$, and " $\mathrm{R}$ " for the stirring rate in rpm, followed by a number representing the value of the variable. Then, the samples prepared were $t 6, \mathrm{t} 15, \mathrm{t} 20$, and $\mathrm{t} 24 ; \mathrm{T} 25, \mathrm{~T} 30$, T40, and T55; and R400, R700, and R1000 for studies of time, temperature and stirring rate, respectively. The sample synthesized at $24 \mathrm{~h}, 40^{\circ} \mathrm{C}$, and $700 \mathrm{rpm}$ is common to the three series done. To compare results, this sample was named as t24, T40, and R700, depending on the study discussed. All experiments were duplicated, and the reproducibility of the results was similar to that describe elsewhere [45].

\subsubsection{Characterization}

X-ray Diffraction (XDR)

Samples were radiated with the emission of $\mathrm{CuK} \alpha(\lambda \mathrm{K} \alpha=0.15406 \mathrm{~nm})$, between 0 and $5^{\circ}(2 \theta)$ with a step size of $0.01^{\circ}$ and time step of $18.87 \mathrm{~s}$. A Bruker CCD-Apex monocrystals XR diffractometer containing an X-ray tube with a Mo anode and KRYOFLEX low-temperature equipment was used. The unit cell parameter was calculated as $\mathrm{a} 0=2 \mathrm{~d} / \sqrt{ } 3$, where $\mathrm{d}$ was calculated as $\mathrm{d}=\lambda / 2 \sin \theta$.

\section{$\mathrm{N}_{2}$ Adsorption Isotherms}

An AUTOSORB-6 from Quantachrome was employed to determine the porous texture properties of the synthesized materials. $\mathrm{N}_{2}$ adsorption isotherms at $77 \mathrm{~K}$ were obtained, and the micropore volume and surface area were calculated according to the DubininRaduskevich and BET method, respectively. The total volume was determined from the $\mathrm{N}_{2}$ adsorbed at $\mathrm{P} / \mathrm{P}_{0}=0.965$. The $\mathrm{BJH}$ model, which was applied to the desorption branch of the isotherm, was used to determine the pore size distribution.

Scanning Electron Microscope (SEM)

Samples were covered with gold employing a metallizer $(\mathrm{Au})$ /evaporator $(\mathrm{C})$ from BALZERS, SCD 004 model (Balzers, Liechtenstein). SEM micrographs were obtained with a scanning electron microscope from JEOL, model JSM-840 (Tokio, Japan), operating at $15 \mathrm{kV}$.

\section{Apparent Density}

The apparent density is a very important property of these materials, especially when they have to be mixed with tobacco [45]. The apparent density was measured as the mass of SBA-15 occupying a given volume. Sample holders were filled gently, as they were poured without pressing the SBA-15, and we ensured that all samples were handled in similar conditions. This parameter was determined by triplicate, and deviations lower than $95 \%$ were obtained. 


\subsection{Smoking Analysis}

\subsubsection{Cigarette Preparation}

The procedure carried out was based on the ISO 3402 standard [48]. For each analysis, 10 cigarettes were prepared and conditioned for at least $48 \mathrm{~h}$ under at $22{ }^{\circ} \mathrm{C}$ and $60 \%$ of relative humidity, and they were finally smoked in a smoking machine. Previously, to ensure the homogeneity of the tobacco used for all experiments, the cigarettes (of 3R4F tobacco from the Center for Tobacco Reference of Kentucky University) were emptied, mixed and again conditioned, under the same conditions mentioned.

To prepare the samples' tobacco-additive, the tobacco was wet with $0.1 \mathrm{~g}$ of ethanol per cigarette to favor the mixture with the catalyst. After that, the additive (i.e., 4.8 weight percentage) was added to the tobacco and homogeneously mixed. The mixtures were conditioned as previously described and, finally, the previously emptied tubes of 3R4F tobacco were refilled with the tobacco catalyst mixtures. Moreover, a sample reference was prepared. In this case, tobacco was manipulated in similar way, in that it was wet with $\mathrm{EtOH}$, and tubes were refilled with 3R4F tobacco.

\subsubsection{Smoking Experiment}

The capacity of the smoking machine used is 5 cigarettes per test, using the ISO 3308 [49] smoking regime (i.e., $35 \mathrm{~mL}$ puffs of a duration of $2 \mathrm{~s}$ every $60 \mathrm{~s}$ ). The pressure of aspiration of the smoking machine never exceeds $1.5 \mathrm{kPa}$.

In our experiments, the mainstream smoke passes through the cigarette filter and two traps until arriving to the gas collection Tedlar bag. The first trap is a filter of cellulose acetate of $8 \mathrm{~mm}$, which is commonly used to prepare "roll-your-own" cigarettes (filter per cigarette). The second trap is a $47 \mathrm{~mm}$ diameter Whatman filter glass microfiber (for collecting the smoke of the 10 cigarettes for the study of each SBA-15 sample). Compounds collected in both traps (total particulate matter) and those in the Tedlar bags (gas fraction) were analyzed.

\subsubsection{Analysis of the Vapor Phase}

Compounds collected in the Tedlar bag were analyzed using two methods. On the one hand, $\mathrm{CO}$ and $\mathrm{CO}_{2}$ were determined with an Agilent 6890N GC gas chromatographer with a G2747A methanizer and a packet column Porapak (Porapak Q 80-100 mesh) at $60{ }^{\circ} \mathrm{C}$. Here, $100 \mu \mathrm{L}$ of gas sample was injected at $150^{\circ} \mathrm{C}$ and transported with helium (carrier gas flow rate $40 \mathrm{~mL} \cdot \mathrm{min}^{-1}$ ). Temperatures of the catalyst and the flame ionizer detector (FID) were 375 and $300{ }^{\circ} \mathrm{C}$, respectively. On the other hand, the rest of the volatile compounds were quantified by GC/FID by using an Agilent $6890 \mathrm{~N}$ chromatographer with a GS-GASPRO column. In this analysis, $150 \mu \mathrm{L}$ of gas were injected. The temperatures of the injector and the detector were 150 and $210^{\circ} \mathrm{C}$, respectively. The GC oven program for this analysis was the following: $35^{\circ} \mathrm{C}$ for $5 \mathrm{~min}$, a first ramp of $5{ }^{\circ} \mathrm{C} \cdot \mathrm{min}^{-1}$ until $100{ }^{\circ} \mathrm{C}$, a second ramp of $15^{\circ} \mathrm{C} \cdot \mathrm{min}^{-1}$ until $200^{\circ} \mathrm{C}$, and finally held for $10 \mathrm{~min}$.

\subsubsection{Analysis of the Particulate Matter}

The total particulate matter (TPM) collected in the two types of filters (the cellulose acetate filter and the Whatman microfilter) was calculated from the difference between the weight of the filters before and after the smoking experiment. These two filter types were weighed together, and the procedure was continued according to the ISO 4387 [50]. Results are represented as $\mathrm{mg}$ of tar/g of tobacco smoked. Unburned tobacco in the butt was also determined.

Components retained in the traps were extracted by three successive additions of $20 \mathrm{~mL}$ of 2-propanol (Fisher Chemical, Loughborough, UK). Here, $1 \mu \mathrm{L}$ of this extract was injected (injector temperature $250{ }^{\circ} \mathrm{C}$ ), and the GC oven program was as follows: $40{ }^{\circ} \mathrm{C}$ for $5 \mathrm{~min}$, ramp of $12{ }^{\circ} \mathrm{C} \cdot \mathrm{min}^{-1}$ until $320^{\circ} \mathrm{C}$, and finally held for $25 \mathrm{~min}$. The extracts were analyzed by GC/MS with an Agilent $6890 \mathrm{~N}$ gases chromatographer (column HP5- 
MS) coupled to a mass spectrometer detector Agilent 5973N with an ionization source by electron impact (EI) and quadrupole analyzer. Helium was used as carrier gas.

The SBA-15 materials were synthesized and characterized by duplicate. Smoking runs were also replicated, and the results are the average of the two runs. Large deviations were obtained for the relative amount of the different compounds in the smoking experiments; they were found to be lower than $15 \%$, which is commonly accepted for this type of experiments.

\section{Conclusions}

The effect of time, temperature, and stirring rate in the precipitation stage of the synthesis of SBA-15, on the properties developed by the different materials obtained, as well as on their behavior in the tobacco smoking process, has been studied.

All samples synthesized under the conditions studied present the characteristics of SBA-15 type materials with typical hexagonal $\mathrm{p} 6 \mathrm{~mm}$ structure and textural properties within the usual range. The BET area, the total pore volume, and the pore diameter seemed to decrease, while the micropore volume is maintained when reaction time increases. The increase in temperature during this stage showed an opposite effect on the total pore volume and diameter, although the pore diameter reached a maximum at $40{ }^{\circ} \mathrm{C}$. At $700 \mathrm{rpm}$ of stirring rate, another maximum was observed in the textural parameters. The temperature had a marked effect on the morphology of the particles obtained, yielding conglomerates of rod-like particles at 25 and $30{ }^{\circ} \mathrm{C}$. Fibers were obtained at 40 and $55^{\circ} \mathrm{C}$. The stirring rate had a marked effect on the morphology; it favors the longitudinal growth of the fibers when increased to $700 \mathrm{rpm}$ but then caused the break at a higher stirring rate. Likewise, all SBA- 15 samples showed a fibrous structure except those synthesized at 25 and $30^{\circ} \mathrm{C}$, where the structure was formed by agglomerates of cylinders (rods), without reaching the formation of the fibers.

The sample synthesized at $15 \mathrm{~h}$ showed a low capability in reducing the toxicant compounds in tobacco smoke. The temperature and stirring rate showed a more marked effect on reduction ability, with both variables exhibiting a marked maximum at $40{ }^{\circ} \mathrm{C}$ and $700 \mathrm{rpm}$, respectively. A negative correlation with apparent density and a positive correlation with total pore volume were observed with the reduction capacity of the materials synthesized under the different conditions studied. The morphology of the samples, by microscopy, provides a rough explanation for the apparent density developed by the different materials obtained. The optimal synthesis conditions for reducing the toxicants in tobacco smoke are $24 \mathrm{~h}, 40^{\circ} \mathrm{C}$, and $700 \mathrm{rpm}$.

Author Contributions: Conceptualization, N.J.-S. and A.M.; methodology, N.J.-S. and A.M.; validation, N.J.-S. and A.M.; investigation, N.J.-S. and J.A.; data curation, N.J.-S. and I.B.; writing-original draft preparation, N.J.-S.; writing—review and editing, N.J.-S., M.B., and A.M.; visualization, N.J.-S.; project administration, A.M.; funding acquisition, A.M. All authors have read and agreed to the published version of the manuscript.

Funding: This research received funding from the Spanish Government, project CTQ2015-70726-P (MINECO/FEDER) and the Valencian Conselleria d'Educació, Investigació, Cultura I Esport, project PROMETEO/2016/056, and GV-IDIFEDER 2018/009.

Acknowledgments: Authors wish to thank the Spanish Government, project CTQ2015-70726-P (MINECO/FEDER) and the Valencian Conselleria d'Educació, Investigació, Cultura I Esport, project PROMETEO/2016/056, and GV-IDIFEDER 2018/009 for financial support.

Conflicts of Interest: The authors declare no conflict of interest.

\section{Appendix A}

Individual results of reduction percentages (\%) of the different compounds identified in the collected gas fraction for the tobacco-catalyst with respect to the tobacco 3R4F noncatalyst sample for the study of time, temperature, and stirring rate in the first step of the synthesis of SBA-15. 


\begin{tabular}{|c|c|c|c|c|c|c|c|c|c|c|c|c|}
\hline Compound & Family & t6 & t15 & t20 & t24 & T25 & T30 & $\mathrm{T} 40$ & T55 & R400 & R700 & R1000 \\
\hline Methane & Paraffins & 34.2 & 29.4 & 21.9 & 21.2 & 8.5 & 0.7 & 21.2 & 2.6 & 12.1 & 21.2 & 23.9 \\
\hline Ethane & Paraffins & 33.6 & 29.3 & 20.4 & 22.4 & 1.0 & -3.7 & 22.4 & -1.5 & 14.5 & 22.4 & 24.8 \\
\hline Ethylene & Olefins & 29.5 & 30.2 & 19.6 & 20.7 & -0.2 & -8.5 & 20.7 & -5.3 & 8.3 & 20.7 & 20.4 \\
\hline Ethyne & Others & 27.8 & 46.9 & 21.3 & 6.7 & -7.3 & -22.0 & 6.7 & -13.9 & -4.5 & 6.7 & 17.1 \\
\hline Propane & Paraffins & 32.1 & 28.4 & 18.7 & 18.1 & 0.6 & -5.8 & 18.1 & -8.7 & 11.7 & 18.1 & 23.3 \\
\hline Propene & Olefins & 31.2 & 28.8 & 25.3 & 25.0 & 0.7 & -3.9 & 25.0 & -4.0 & 13.7 & 25.0 & 23.2 \\
\hline Iso-butane & Paraffins & 25.1 & 23.7 & 23.9 & -9.2 & -24.0 & -20.3 & -9.2 & -54.5 & -23.0 & -9.2 & 13.4 \\
\hline Chloromethane & Others & 35.3 & 31.7 & 25.3 & 31.6 & 0.2 & -4.3 & 31.6 & -3.1 & 16.2 & 31.6 & 25.7 \\
\hline Butane & Paraffins & 33.4 & 22.2 & 22.3 & 9.4 & -3.7 & -9.7 & 9.4 & -36.2 & -0.9 & 9.4 & 24.3 \\
\hline 1-Butene & Olefins & 33.9 & 31.3 & 20.7 & 28.1 & 3.4 & -5.6 & 28.1 & -4.8 & 17.6 & 28.1 & 24.3 \\
\hline 1,2-Propadiene & Olefins & 39.9 & 47.6 & 32.0 & 28.6 & -2.7 & -34.2 & 28.6 & -13.5 & 20.8 & 28.6 & 29.7 \\
\hline 1,3-Butadiene & Olefins & 31.6 & 23.5 & 14.1 & 26.6 & -2.6 & 1.9 & 26.6 & -7.1 & 14.9 & 26.6 & 25.8 \\
\hline Isobutene & Olefins & 30.3 & 25.9 & 15.1 & 25.6 & -13.0 & -10.1 & 25.6 & -18.6 & 12.8 & 25.6 & 21.1 \\
\hline cis-2-Butene & Olefins & 35.2 & 31.1 & 20.0 & 26.8 & -5.2 & -3.6 & 26.8 & -9.5 & 16.7 & 26.8 & 24.1 \\
\hline Pentane & Paraffins & 36.2 & 31.9 & 20.2 & 21.3 & -6.5 & -11.0 & 21.3 & -11.6 & 14.7 & 21.3 & 22.5 \\
\hline Methanethiol & Others & 37.9 & 27.9 & 27.4 & 34.5 & -11.9 & -0.5 & 34.5 & 2.7 & 20.5 & 34.5 & -5.0 \\
\hline Hydrogen cyanide & Others & 26.5 & 18.4 & 14.1 & 22.0 & -1.4 & -28.0 & 22.0 & -21.1 & 4.9 & 22.0 & 14.3 \\
\hline 1-Pentene & Olefins & 28.1 & 29.0 & 14.9 & 25.0 & -6.0 & -7.9 & 25.0 & -12.3 & 10.0 & 25.0 & 23.8 \\
\hline Furan & Aromatics & 34.3 & 30.7 & 23.1 & 37.5 & -8.0 & 10.3 & 37.5 & 4.5 & 26.3 & 37.5 & 24.2 \\
\hline Isoprene & Olefins & 25.0 & 16.1 & 10.6 & 19.1 & 20.6 & -14.1 & 19.1 & -4.2 & -6.7 & 19.1 & 17.2 \\
\hline Hexane & Paraffins & 24.0 & -2.2 & -39.6 & 0.8 & 33.8 & -76.9 & 0.8 & -37.5 & -50.8 & 0.8 & 5.1 \\
\hline 1-Hexene & Olefins & 30.4 & 27.4 & 20.2 & 25.0 & -13.3 & -8.0 & 25.0 & -23.2 & 9.7 & 25.0 & 19.4 \\
\hline Benzene & Aromatics & 52.3 & 46.0 & 44.7 & 44.3 & 39.5 & 37.0 & 44.3 & 45.1 & 37.9 & 44.3 & 34.8 \\
\hline Acetaldehyde & Aldehydes & 46.6 & 42.2 & 38.5 & 35.6 & -78.8 & -66.7 & 35.6 & -83.3 & 35.5 & 35.6 & 32.0 \\
\hline Acrolein & Aldehydes & 3.5 & -10.3 & -18.8 & 4.0 & -58.5 & -44.4 & 4.0 & -58.5 & -23.7 & 4.0 & -34.5 \\
\hline Propionaldehyde & Aldehydes & 50.9 & 38.4 & 29.7 & 44.9 & 6.4 & 10.9 & 44.9 & 9.3 & 37.5 & 44.9 & 29.4 \\
\hline Acetonitrile & Others & 56.2 & 61.2 & 68.4 & 71.5 & 45.3 & 76.3 & 71.5 & 60.7 & 83.3 & 71.5 & 47.3 \\
\hline Toluene & Aromatics & 45.7 & 43.4 & 36.7 & 48.0 & 12.3 & 20.3 & 48.0 & 18.6 & 48.0 & 48.0 & 29.5 \\
\hline 2,5-Dimethylfuran & Aromatics & 49.6 & 35.4 & 37.4 & 48.2 & -8.7 & 8.0 & 48.2 & -7.9 & 45.4 & 48.2 & 36.5 \\
\hline Crotonaldehyde & Aldehydes & 31.5 & -62.2 & 4.2 & 33.6 & -224.9 & 30.9 & 33.6 & -27.5 & -2.6 & 33.6 & -17.4 \\
\hline Isobutyraldehyde & Aldehydes & 45.0 & 29.4 & 20.0 & 25.3 & -18.4 & -12.3 & 25.3 & -10.7 & 37.9 & 25.3 & 20.1 \\
\hline
\end{tabular}

\section{Appendix B}

Individual results of reduction percentages (\%) of the different compounds identified in the collected total particulate matter fraction for the tobacco-catalyst with respect to the tobacco 3R4F non-catalyst sample for the study of time, temperature, and stirring rate in the first step of the synthesis of SBA- 15 . 


\begin{tabular}{|c|c|c|c|c|c|c|c|c|c|c|c|c|}
\hline Compound & Family & t6 & t15 & t20 & t24 & $\mathrm{T} 25$ & T30 & T40 & T55 & R400 & R700 & R1000 \\
\hline 2-(1-methylethoxy)-Ethanol & Epoxies & 76.3 & 57.9 & 54.3 & 82.5 & 75.4 & 80.4 & 82.5 & 74.2 & 54.4 & 82.5 & 51.1 \\
\hline 1-(acetyloxy)-2-Propanone & Carbonyls & 100.0 & 100.0 & 100.0 & 100.0 & 100.0 & 100.0 & 100.0 & 100.0 & 100.0 & 100.0 & 100.0 \\
\hline Styrene & Others & 100.0 & 100.0 & 100.0 & 100.0 & 100.0 & 100.0 & 100.0 & 46.9 & 100.0 & 100.0 & 100.0 \\
\hline 2-methyl-2-Cyclopenten-1-one & Carbonyls & 100.0 & 100.0 & 100.0 & 100.0 & 100.0 & 100.0 & 100.0 & 71.7 & 100.0 & 100.0 & 100.0 \\
\hline 2,5-Dimethyl-2-cyclopentenone & Carbonyls & 100.0 & 100.0 & 100.0 & 100.0 & 79.3 & 89.6 & 100.0 & 100.0 & 100.0 & 100.0 & 100.0 \\
\hline Phenol & Phenols & 85.3 & 79.4 & 85.9 & 92.7 & -14.2 & 86.7 & 92.7 & 26.2 & 80.8 & 92.7 & 69.7 \\
\hline 2-hydroxy-3-methyl-2-Cyclopenten-1-one & Carbonyls & 85.3 & 85.8 & 96.4 & 95.3 & 39.1 & 41.2 & 95.3 & 59.8 & 91.5 & 95.3 & 68.2 \\
\hline Limonene & Others & 66.2 & 55.2 & 64.0 & 66.3 & 57.0 & 70.6 & 66.3 & 66.8 & 46.5 & 66.3 & -7.5 \\
\hline 2,3-Dimethyl-2-cyclopenten-1-one & Carbonyls & 100.0 & 105.7 & 100.0 & 100.0 & 81.2 & 82.7 & 100.0 & 65.6 & 100.0 & 100.0 & 100.0 \\
\hline o-Cresol & Phenols & 73.9 & 64.1 & 79.4 & 88.3 & 73.2 & 91.1 & 88.3 & 77.6 & 73.1 & 88.3 & 61.1 \\
\hline $\mathrm{p}$-Cresol & Phenols & 82.2 & 78.2 & 83.3 & 89.9 & 65.9 & 82.1 & 89.9 & 77.3 & 82.4 & 89.9 & 68.5 \\
\hline 2-methoxy-Phenol & Phenols & 88.9 & 87.9 & 92.2 & 97.6 & 68.0 & 90.3 & 97.6 & 57.2 & 94.0 & 97.6 & 72.7 \\
\hline 2-Propanamine & Nitrogenous & 100.0 & 100.0 & 100.0 & 100.0 & 100.0 & 100.0 & 100.0 & 100.0 & 100.0 & 100.0 & 100.0 \\
\hline 3-Ethyl-2-hydroxy-2-cyclopenten-1-one & Carbonyls & 85.0 & 88.6 & 89.8 & 94.4 & 74.5 & 90.0 & 94.4 & 82.7 & 91.4 & 94.4 & 81.5 \\
\hline 2,3-Dihydro-3,5-dihydroxy-6-methyl-4H-pyran-4-one & Carbonyls & 69.7 & 65.0 & 70.4 & 81.3 & 61.3 & 46.1 & 81.3 & 52.4 & 63.4 & 81.3 & 53.5 \\
\hline 2,4-dimethyl-Phenol & Phenols & 82.9 & 75.8 & 78.4 & 93.1 & 51.1 & 84.7 & 93.1 & 100.0 & 71.1 & 93.1 & 59.4 \\
\hline 4-ethyl-Phenol & Phenols & 69.8 & 65.6 & 66.9 & 86.0 & 100.0 & 64.6 & 86.0 & 68.1 & 67.3 & 86.0 & 50.5 \\
\hline Naphthalene & Others & 100.0 & 100.0 & 100.0 & 100.0 & -20.0 & 59.1 & 100.0 & 63.1 & 100.0 & 100.0 & 100.0 \\
\hline 1-(3-methylphenyl)-Ethanone & Carbonyls & 100.0 & 100.0 & 100.0 & 100.0 & 77.2 & 78.3 & 100.0 & 94.0 & 100.0 & 100.0 & 100.0 \\
\hline p-cresol 2 methoxy & Phenols & 100.0 & 100.0 & 100.0 & 100.0 & 83.1 & 89.6 & 100.0 & 81.9 & 100.0 & 100.0 & 100.0 \\
\hline 2,3-Dihydro-benzofuran & Epoxies & 59.5 & 58.1 & 61.9 & 85.5 & 100.0 & 100.0 & 85.5 & 100.0 & 60.4 & 85.5 & 56.0 \\
\hline Hydroquinone & Phenols & 40.2 & 32.4 & 38.2 & 41.3 & -31.9 & -35.7 & 41.3 & -11.7 & 31.4 & 41.3 & 55.9 \\
\hline $1 H$-Indole & Nitrogenous & 59.6 & 47.7 & 26.0 & 46.7 & 70.5 & 69.6 & 46.7 & 73.3 & 32.8 & 46.7 & 52.4 \\
\hline
\end{tabular}




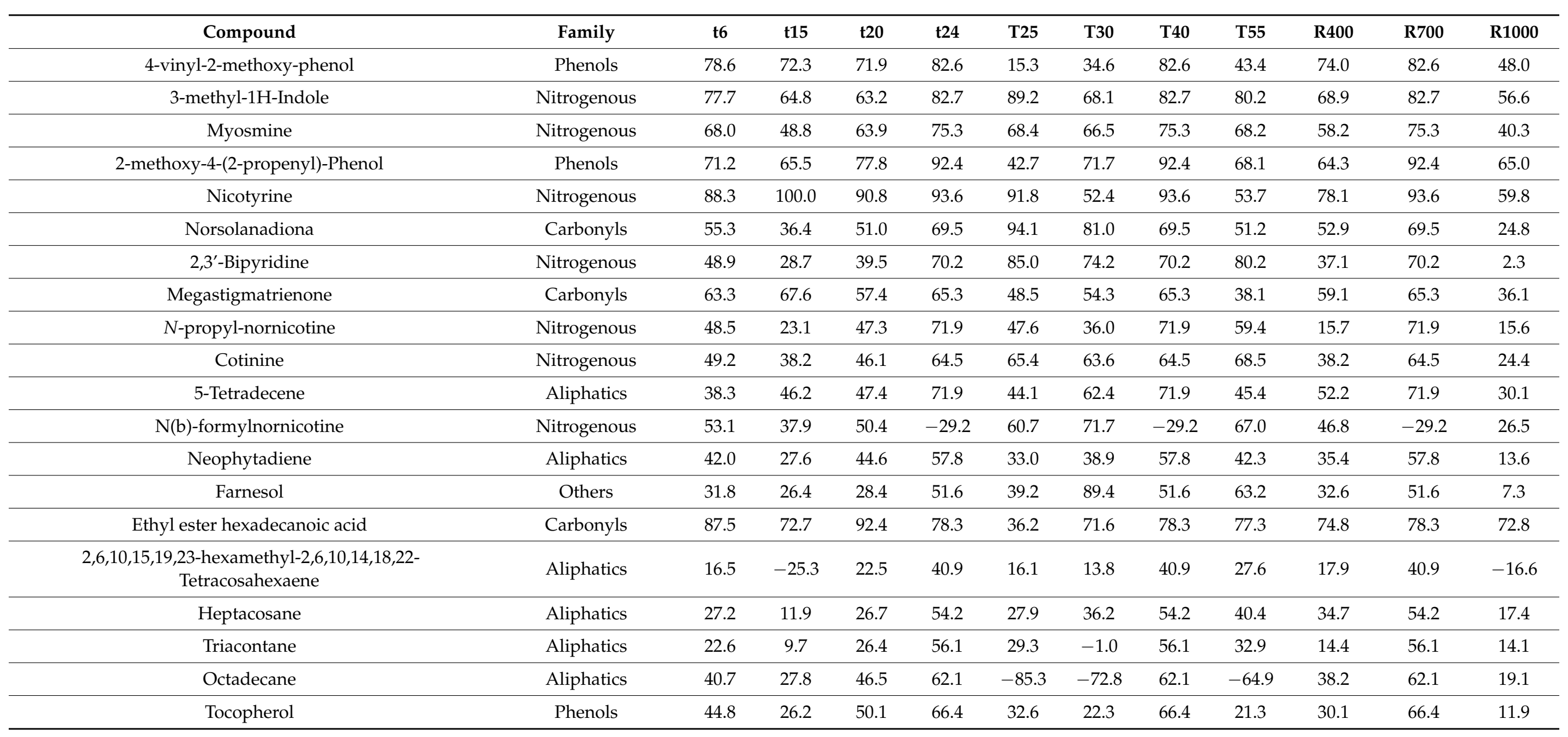




\section{References}

1. Musk, A.W.; De Klerk, N.H. History of tobacco and health. Respirology 2003, 8, 286-290. [CrossRef]

2. The Health Consequences of Smoking, Atlanta (GA). 2004. Available online: https://www.cdc.gov/tobacco/data_statistics/sgr/ 2004/pdfs/tableofcontents.pdf (accessed on 3 September 2018).

3. Taylor, A.E.; Johnson, D.C.; Kazemi, H. AHA Medical/Scientific Statement Position Statement Environmental Tobacco Smoke and Cardiovascular Disease A Position Paper From the Council on Cardiopulmonary and Critical Care. Circulation 1992, 86, 699-702. [CrossRef]

4. Chan-Yeung, M.; Dimich-Ward, H. Respiratory health effects of exposure to environmental tobacco smoke. Respirology 2003, 8 , 131-139. [CrossRef] [PubMed]

5. Hofhuis, W.; De Jongste, J.C.; Merkus, P.J.F.M. Adverse health effects of prenatal and postnatal tobacco smoke exposure on children. Arch. Dis. Child. 2003, 88, 1086-1090. [CrossRef]

6. WHO. WHOI Tobacco control measures. 2013. Available online: http://www.who.int/tobacco/control/measures/en/ (accessed on 4 September 2018).

7. Clancy, L. International Policies to Reduce Tobacco Use. Interv. Addict. 2013, 745-755. [CrossRef]

8. Hopkins, D.P.; Razi, S.; Leeks, K.D.; Kalra, G.P.; Chattopadhyay, S.K.; Soler, R.E. Smokefree Policies to Reduce Tobacco Use. A Systematic Review, AMEPRE. Am. J. Prev. Med. 2010, 38, S275-S289. [CrossRef] [PubMed]

9. Levy, D.T.; Wen, C.P.; Chen, T.Y.; Oblak, M. Increasing taxes to reduce smoking prevalence and smoking attributable mortality in Taiwan: Results from a tobacco policy simulation model. Tob. Control. 2005, 14, i45-i50. [CrossRef]

10. Brownson, R.C.; Eriksen, M.P.; Davis, R.M.; Warner, K.E. 5:4 Annual Reviews AR028-07 AR28-07 Environmental Tobacco Smoke: Health Effects and Policies to Reduce Exposure * 15:4 Annual Reviews AR028-07 AR28-07 164. 1997. Available online: www.annualreviews.org (accessed on 3 September 2018).

11. Inquiries \& Reports Archives - Action on Smoking and Health. 2018. Available online: http://ash.org.uk/category/about-ash/ all-party-parliamentary-group-on-smoking-health/inquiries-reports / (accessed on 4 September 2018).

12. Smoking Is Down, But Almost 38 Million American Adults Still Smoke I CDC Online Newsroom I CDC. 2018. Available online: https:/ / www.cdc.gov/media/releases/2018/p0118-smoking-rates-declining.html (accessed on 4 September 2018).

13. European-Parliament; Council-of-the-European-Union. DIRECTIVE 2014/40/EU of the european parliament and of the council of 3 April 2014 on the approximation of the laws, regulations and administrative provisions of the Member States concerning the manufacture, presentation and sale of tobacco and related pr. Off. J. Eur. Union. L 2014, 127, 1-38.

14. Marcilla, A.; Beltrán, M.I.; Siurana, A.G.; Martínez, I.; Berenguer, D. Effect of the Concentration of Siliceous Materials Added to Tobacco Cigarettes on the Composition of the Smoke Generated during Smoking. Ind. Eng. Chem. Res. 2015, 54, 1916-1929. [CrossRef]

15. Meier, W.; Siegmann, K. Significant reduction of carcinogenic compounds in tobacco smoke by the use of zeolite catalysts. Microporous Mesoporous Mater. 1999, 33, 307-310. [CrossRef]

16. Marcilla, A.; Gómez-Siurana, A.; Berenguer, D.; Martínez-Castellanos, I.; Beltrán, M. Reduction of tobacco smoke components yield in commercial cigarette brands by addition of HUSY, NaY and Al-MCM-41 to the cigarette rod. Toxicol. Rep. 2015, 2, 152-164. [CrossRef] [PubMed]

17. Marcilla, A.; Gómez-Siurana, A.; Berenguer, D.; Martínez-Castellanos, I.; Beltrán, M. Reduction of tobacco smoke components yields by zeolites and synthesized Al-MCM-41. Microporous Mesoporous Mater. 2012, 161, 14-24. [CrossRef]

18. Lin, W.G.; Zhou, Y.; Cao, Y.; Zhou, S.L.; Wan, M.M.; Wang, Y.; Zhu, J.H. Applying heterogeneous catalysis to health care: In situ elimination of tobacco-specific nitrosamines (TSNAs) in smoke by molecular sieves. Catal. Today 2013, 212, 52-61. [CrossRef]

19. Dan, H.; Chen, L.; Xian, Q.; Yi, F.; Ding, Y. Tailored synthesis of SBA-15 rods using different types of acids and its application in adsorption of uranium. Sep. Purif. Technol. 2019, 210, 491-496. [CrossRef]

20. Bera, B.; Das, N. Synthesis of high surface area mesoporous silica SBA-15 for hydrogen storage application. Int. J. Appl. Ceram. Technol. 2018, 16, 294-303. [CrossRef]

21. Yousofvand, Z.; Hajjami, M.; Ghorbani, F.; Ghafouri-Nejad, R. Synthesis of Ni(II)-3,5-dichloro-2-hydroxybenzenesulfonyl chloride supported SBA-15 and its application as a nanoreactor catalyst for the synthesis of diaryl sulfides via reaction of aryl halides with thiourea or S8. J. Porous Mater. 2017, 25, 1349-1358. [CrossRef]

22. Zhang, M.; Chu, B.; Li, G.; Xiao, J.; Zhang, H.; Peng, Y.; Li, B.; Xie, P.; Fan, M.; Dong, L. Triethanolamine-modified mesoporous SBA-15: Facile one-pot synthesis and its catalytic application for cycloaddition of $\mathrm{CO} 2$ with epoxides under mild conditions. Microporous Mesoporous Mater. 2019, 274, 363-372. [CrossRef]

23. Crucianelli, M.; Bizzarri, B.M.; Saladino, R. SBA-15 Anchored Metal Containing Catalysts in the Oxidative Desulfurization Process. Catalysts 2019, 9, 984. [CrossRef]

24. Bizzarri, B.M.; Fanelli, A.; Piccinino, D.; De Angelis, M.; Dolfa, C.; Palamara, A.T.; Nencioni, L.; Zippilli, C.; Crucianelli, M.; Saladino, R.; et al. Synthesis of Stilbene and Chalcone Inhibitors of Influenza A Virus by SBA-15 Supported Hoveyda-Grubbs Metathesis. Catalysts 2019, 9, 983. [CrossRef]

25. Boutros, M.; Gálvez, M.E.; Onfroy, T.; Da Costa, P. Influence of synthesis parameters of SBA-15 supported palladium catalysts for methane combustion and simultaneous NOx reduction. Microporous Mesoporous Mater. 2014, 183, 1-8. [CrossRef] 
26. Koh, M.H.; Azaman, S.A.H.; Hameed, B.H.; Din, A.T.M. Surface morphology and physicochemical properties of ordered mesoporous silica SBA-15 synthesized at low temperature. IOP Conf. Ser. Mater. Sci. Eng. 2017, 206, 012056. [CrossRef]

27. Alfredsson, V.; Wennerström, H. The Dynamic Association Processes Leading from a Silica Precursor to a Mesoporous SBA-15 Material. Acc. Chem. Res. 2015, 48, 1891-1900. [CrossRef]

28. Long, H.; Wang, W.; Yang, W.; Wang, Y.; Ru, H. Facile and controllable preparation of different SBA-15 platelets and their regulated drug release behaviours. Microporous Mesoporous Mater. 2018, 263, 34-41. [CrossRef]

29. Thielemann, J.P.; Girgsdies, F.; Schlögl, R.; Hess, C. Pore structure and surface area of silica SBA-15: Influence of washing and scale-up. Beilstein J. Nanotechnol. 2011, 2, 110-118. [CrossRef]

30. Lee, H.I.; Kim, J.H.; Stucky, G.D.; Shi, Y.; Pak, C.; Kim, J.M. Morphology-selective synthesis of mesoporous SBA-15 particles over micrometer, submicrometer and nanometer scales. J. Mater. Chem. 2010, 20, 8483-8487. [CrossRef]

31. Fulvio, P.F.; Pikus, S.; Jaroniec, M. Tailoring properties of SBA-15 materials by controlling conditions of hydrothermal synthesis. J. Mater. Chem. 2005, 15, 5049-5053. [CrossRef]

32. Juárez-Serrano, N.; Asensio, J.; Martínez-Castellanos, I.; Beltrán, M.; Marcilla, A. The Effect of Temperature and Time of the Hydrothermal Treatment in the SBA-15 Synthesis Process on the Structure and Textural Properties and the Ability to Reduce the Evolution of Tars in Tobacco Smoking. Catalysts 2020, 10, 272. [CrossRef]

33. Brunauer, S.; Emmett, P.H.; Teller, E. Adsorption of Gases in Multimolecular Layers. J. Am. Chem. Soc. 1938, 60, 309-319. [CrossRef]

34. Dubinin, M.M.; Zhukovskaia, E.G. Adsorption properties of carbon adsorbents Communication 2. Adsorption properties of active carbons with respect to benzene and nitrogen vapors. Bull. Acad. Sci. USSR Div. Chem. Sci. 1958, 7, 519-528. [CrossRef]

35. Barrett, E.P.; Joyner, L.G.; Halenda, P.P. The Determination of Pore Volume and Area Distributions in Porous Substances. I. Computations from Nitrogen Isotherms. J. Am. Chem. Soc. 1951, 73, 373-380. [CrossRef]

36. Benamor, T.; Vidal, L.; Lebeau, B.; Marichal, C. Influence of synthesis parameters on the physico-chemical characteristics of SBA-15 type ordered mesoporous silica. Microporous Mesoporous Mater. 2012, 153, 100-114. [CrossRef]

37. Klimova, T.; Esquivel, A.; Reyes, J.; Rubio, M.; Bokhimi, X.; Aracil, J. Factorial design for the evaluation of the influence of synthesis parameters upon the textural and structural properties of SBA-15 ordered materials. Microporous Mesoporous Mater. 2006, 93, 331-343. [CrossRef]

38. Guillet-Nicolas, R.; Bérubé, F.; Thommes, M.; Janicke, M.T.; Kleitz, F. Selectively Tuned Pore Condensation and Hysteresis Behavior in Mesoporous SBA-15 Silica: Correlating Material Synthesis to Advanced Gas Adsorption Analysis. J. Phys. Chem. C 2017, 121, 24505-24526. [CrossRef]

39. Bérubé, F.; Kaliaguine, S. Calcination and thermal degradation mechanisms of triblock copolymer template in SBA-15 materials. Microporous Mesoporous Mater. 2008, 115, 469-479. [CrossRef]

40. Kruk, M.; Jaroniec, M.; Ko, C.H.; Ryoo, R. Characterization of the Porous Structure of SBA-15. Chem. Mater. 2000, 12, 1961-1968. [CrossRef]

41. Palani, A.; Wu, H.-Y.; Ting, C.-C.; Vetrivel, S.; Shanmugapriya, K.; Chiang, A.S.; Kao, H.-M. Rapid temperature-assisted sonochemical synthesis of mesoporous silica SBA-15. Microporous Mesoporous Mater. 2010, 131, 385-392. [CrossRef]

42. Matos, J.R.; Mercuri, L.P.; Kruk, M.; Jaroniec, M. Synthesis of Large-Pore Silica with Cage-Like Structure Using Sodium Silicate and Triblock Copolymer Template. Langmuir 2002, 18, 884-890. [CrossRef]

43. Carrero, A.; Moreno, J.; Aguado, J.; Calleja, G. Control of SBA-15 materials morphology by modification of synthesis conditions. Stud. Surf. Sci. Catal. 2008, 174, 321-324. [CrossRef]

44. Colilla, M.; Balas, F.; Manzano, M.; Vallet-Regí, M. Novel Method To Enlarge the Surface Area of SBA-15. Chem. Mater. 2007, 19, 3099-3101. [CrossRef]

45. Zhao, D.; Huo, Q.; Feng, J.; Chmelka, B.F.; Stucky, G.D. Nonionic Triblock and Star Diblock Copolymer and Oligomeric Surfactant Syntheses of Highly Ordered, Hydrothermally Stable, Mesoporous Silica Structures. J. Am. Chem. Soc. 1998, 120, 6024-6036. [CrossRef]

46. Rahmat, N.; Hamzah, F.; Sahiron, N.; Mazlan, M.; Zahari, M.M. Sodium silicate as source of silica for synthesis of mesoporous SBA-15. IOP Conf. Ser. Mater. Sci. Eng. 2016, 133, 012011. [CrossRef]

47. Kosuge, K.; Sato, T.; Kikukawa, A.N.; Takemori, M. Morphological Control of Rod- and Fiberlike SBA-15 Type Mesoporous Silica Using Water-Soluble Sodium Silicate. Chem. Mater. 2004, 16, 899-905. [CrossRef]

48. ISO 3402:1999 Tabaco y Productos del Tabaco. 2005. Available online: https://www.une.org/encuentra-tu-norma/busca-tunorma/norma?c=N0034636 (accessed on 1 March 2021).

49. ISO 3308:2000 Routine Analytical Cigarette-Smoking Machine _ Definitions and Standard Conditions. 2000. Available online: https:/ / www.iso.org/standard/28325.html (accessed on 1 March 2021).

50. ISO 4387:2008 Cigarrillos. Determinación del Condensado bruto de Humo y Condensado seco Exento de Nicotina Utilizando una Máquina de Fumar Analítica de Rutina. 2010. Available online: https://www.aenor.com/normas-y-libros/buscador-denormas / une?c=N0041544 (accessed on 1 March 2021). 